\title{
The Coalfields of South-Central Africa: A Current Perspective
}

\author{
P. J. Hancox \\ University of the Witwatersrand, School of Geosciences and Evolutionary Studies Institute, Private Bag 3, 2050 Wits, South Africa. \\ E-mail: jhancox@cciconline.com
}

DOI: 10.18814/epiiugs/2016/v39i2/95785

Africa is host to coal deposits stretching from the far north to the far south and ranging in age from the Carboniferous through to the Miocene. Coal production in the north of the continent is however currently of a very limited nature compared to that in the south, where due mainly to its low cost and relative abundance, the commodity has long been the primary source of energy. Coal is also used extensively in the metallurgical (titanium, ferrochrome, ferromanganese and steel) industries. All of the main exploited coal deposits in South-Central Africa are hosted in sedimentary rocks of the Late Carboniferous to Middle Jurassic aged, Karoo Supergroup and their temporal equivalents. Apart from being the host to the regions' coals, the Karoo aged rocks also contain a world class palaeontological record. This work focusses on the coal deposits of the Karoo basins of South-Central Africa and in particular those countries that are currently producing coal (including South Africa, Botswana, Zimbabwe, Zambia, Mozambique, Malawi and Tanzania) and provides an updated high level overview, focussing on the current status and historical development, general geology (including coal seam nomenclature and general coal qualities) and resource base of each of the main producing coalfields.

\section{Introduction}

Coal deposits are widely distributed across Africa, occurring from Morocco in the north to South Africa in the south. These coals are not all of the same age, being hosted in sedimentary successions ranging from the Carboniferous to the Miocene (Figure 1).

Although coal has the potential to become part of the power generation mix in a number of northern African countries, at present this is not the case, with limited production mainly for local use. This contrasts strongly with the South-Central African (SCA) countries, where coal is the primary source of energy.

Currently South Africa, Botswana, Zimbabwe and Zambia mine coal for utilisation in power generation. Coal is most important to South Africa and Botswana, where it accounts for over $90 \%$ of electricity generation, whereas in Zimbabwe about half the country's power comes from coal fired power stations, the rest being hydroelectric. Zambia also relies heavily on hydropower, but currently some $300 \mathrm{MW}$ of coal fired capacity is being built. Despite its huge coalfields (and various plans for coal-fired power stations) almost all of Mozambique's electricity generation is from hydropower. Although a number of coal fired units are being planned, Tanzania currently uses roughly equal amounts of hydro, natural gas and liquid fuel power plants. Coal is also used extensively in the metallurgical industry, with South Africa, Zimbabwe and Mozambique containing the largest and best resources.

The history of coal mining in SCA goes back well over a century, and during this time various historical works have been published for the various countries that make up the region, the most important of which are documented in the following country specific sections. The first major synthesis of the coalfields of South Africa, Botswana and Zimbabwe may be found in Volume II of the 1986 Mineral Deposits of Southern Africa (Anhaeusser and Maske, 1986). This work was however published long before the major exploration boom in the latter two countries, and before the enactment of the new Mineral and Petroleum Resources Development Act (Act 28 of 2002) in South Africa, which saw a number of new entrants and much information becoming freely available on various company websites, as well as on the Canadian Stock Exchange's System for Electronic Data Storage and Retrieval (http://www.sedar.com).

The establishment of the Fossil Fuel Foundation (http:// www.fossilfuel.co.za/) in late 1994 was also an important milestone in our understanding of the coalfields of SCA. Since 1995 this organisation has hosted numerous coal technical events, many of which have been country, region or coalfield focussed, and at which much new knowledge has been disseminated, a great deal of which is not otherwise available in the public or scientific domains.

The formulation of the South African Mineral Resource Committee (SAMREC) Code and its initial issue in March of 2000 was another milestone for the coal industry of South Africa. The code has been updated a number of times and at present coal resources in South Africa must be estimated in accordance with the SAMREC (2007) Code, as well as the South African Guide to the Systematic Evaluation of Coal Resources and Coal Reserves (SANS 10320:2004).

Cairncross (2001) provided a then up to date review of the Permian (Karoo aged) coal deposits of South Africa, Swaziland, Botswana, Namibia, Zimbabwe, Zambia, Mozambique, Malawi and Tanzania. Whilst this paper is now some 15 years old, it still provides an excellent background. Catuneanu et al. (2005) built on this work and synthesised the sedimentological and stratigraphic features of the Karoo basins of SCA, highlighting the tectonic and climatic controls on the generation and fill of accommodation space.

This paper draws from all these previous works, as well as from 


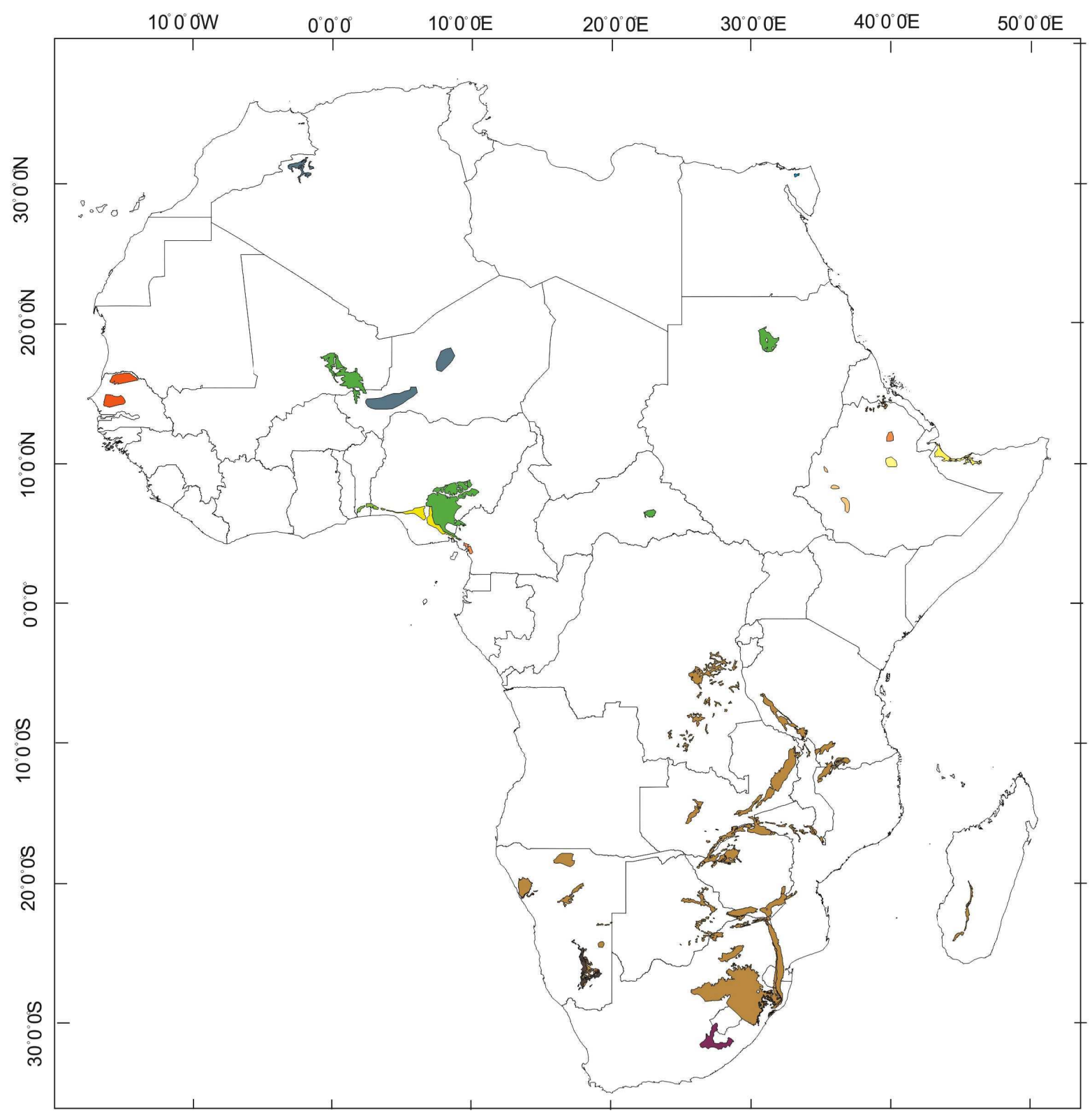

\section{EXPLANATION}

\begin{tabular}{|c|c|c|}
\hline \multirow[t]{2}{*}{ Coal age } & Paleocene & Triassic \\
\hline & Tertiary & Permian \\
\hline Pliocene & Cretaceous- Paleocene & Permian - Carboniferous \\
\hline Miocene & Cretaceous & Carboniferous \\
\hline Eocene-Miocene & lurassic & \\
\hline Middle Eocene-Oligocene & & \\
\hline
\end{tabular}

Figure 1. Map of Africa showing the distribution and ages of the various coal deposits. (From Merrill and Tewaltt, 2008). Note: this map, and the dataset on which it is based, is freely downloadable at http://pubs.usgs.gov/of/2008/1258/.

an extensive historic literature, various open-file reports and company websites, as well as personal experience gained by the author over the past 18 years. Because a lot of data pertaining to the coalfields is of a confidential nature, only publicly available information has been used, particularly when providing coal qualities or resource tonnages. The author has however used his own knowledge to try and make sure that these are as representative as possible of the particular coalfield. Unless otherwise stated all coal qualities provided are on a raw coal, air dried basis. For most coalfields; coal qualities provided include Ash \% (Ash), Calorific Value (CV) in megajoules per kilogram $(\mathrm{MJ} / \mathrm{kg}$ ), Volatile Matter \% (VM) and Total Sulphur \% (TS). Inherent Moisture (IM), Fixed Carbon (FC) and Dry Ash-Free Volatile Matter (DAFVOL) percentages are also presented where available or where they add specific value. 


\section{Regional Geology}

The Karoo basins of SCA evolved during the first-order cycle of supercontinent assembly and breakup of Pangea, under the influence of distinct tectonic regimes (Cairncross, 2001; Catuneanu et al., 2005). Karoo aged rocks are present throughout SCA (Figure 2), but are most widespread in South Africa, where they host all of the country's coal resources.

The Main Karoo Basin of South Africa forms part of a major series of foreland basins that developed through subduction, compression, collision, and terrane accretion, along the southern margin of Gondwana (Cole, 1992; Veevers et al., 1994; Catuneanu et al., 1998). Within this tectonic setting, primary subsidence, and the creation of accommodation space for sedimentary fill, was controlled by flexural (supralithospheric) and dynamic (sublithospheric) loading (Pysklywec and Mitrovica, 1999). It is the most studied and best known SCA basin and has been proposed as the type basin for coalbearing deposits of southern Africa (Cadle et al., 1993).

In South Africa the Karoo Supergroup in the Main Karoo Basin is lithostratigraphically subdivided into the Dwyka, Ecca, Beaufort and Stormberg groups (SACS, 1980; Cole, pers. comm.), each of which have distinct proximal and distal facies, which change across a proposed hinge line (Catuneanu et al., 1998). It is the description of these groups in the distal sector of the Main Karoo Basin that form the lithostratigraphic framework against which all the equivalent Karoo successions in SCA are compared.

Based mainly on dating from palynological studies, coal formation is believed to be restricted to three intervals of geologic time, these being the Early Permian (Artinskian-Kungurian) Ecca Group (Vryheid Formation), the Middle-Late Permian (Ufimian-Kazanian) Beaufort Group, and the Late Triassic (Carnian) Stormberg Group (Molteno Formation). The majority of the presently mined coal seams in South Africa are however of Early Permian age, being comparable to other Gondwanan coals in SCA, Madagascar, India, Australia, Antarctica and South America.

All of the Karoo aged basins of SCA evolved during a first-order cycle of supercontinent assembly and breakup, under the influence of two distinct tectonic regimes. Other than the Triassic Molteno Formation hosted coals, all of the rest within the Main Karoo Basin are hosted in the distal sector, on a stable platform overlying the Kaapvaal Craton. Outside of the Main Karoo Basin of South Africa, which is a compressional retro-foreland basin (Catuneanu et al., 1998), Karoo aged depositories are extensional rift basins, formed as either intra- or inter-cratonic, grabens or half-grabens (Cairncross, 2001).

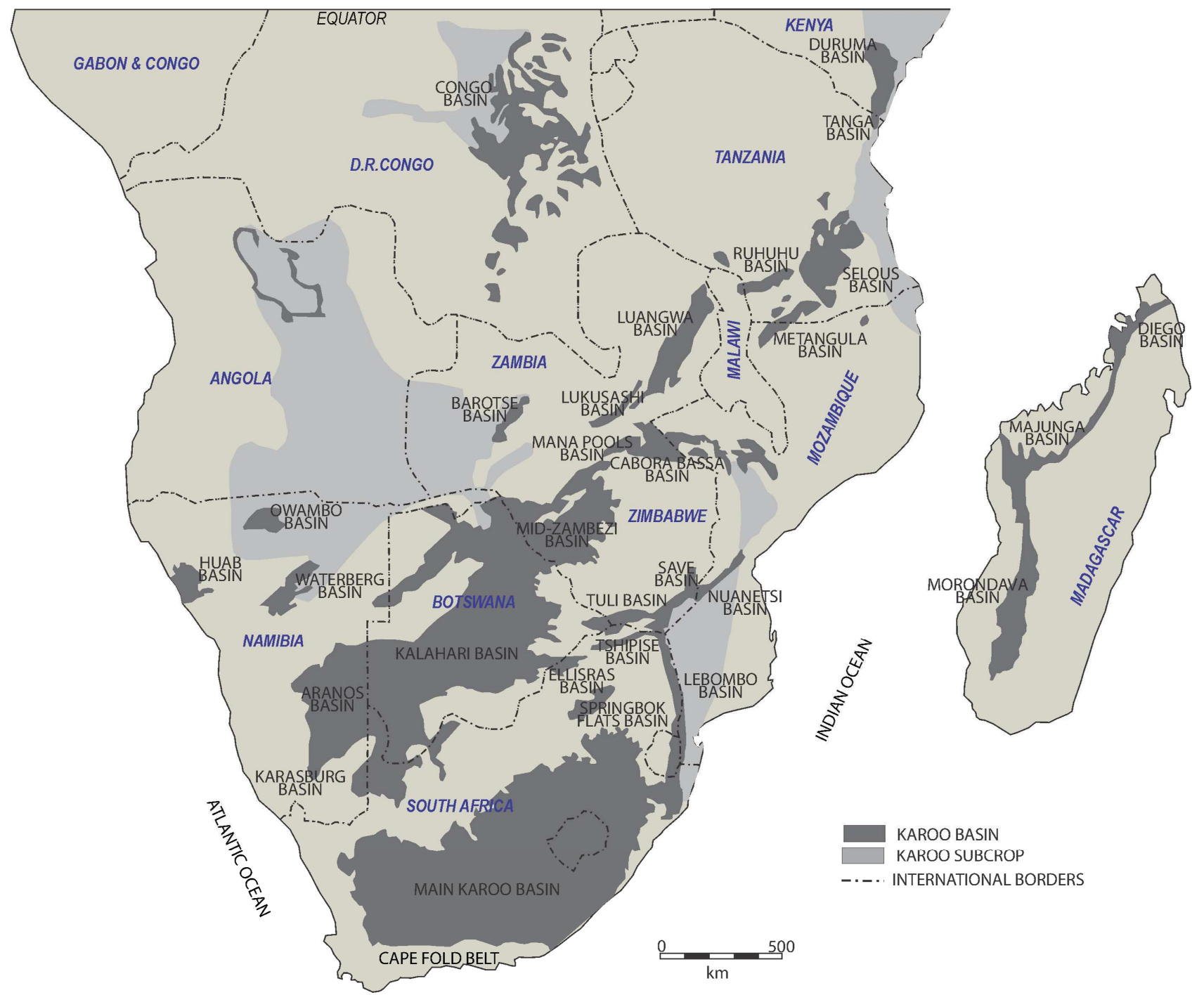

Figure 2. Map showing the various Karoo aged basins of South-Central Africa (From Catuneanu et al., 2005). 
These extensional rift related basins are structurally more complex than their compressional foreland related counterpart in South Africa.

North of the Main Karoo Basin, the tectonic regimes were dominated by extensional or transtensional intraplate stresses that were either linked to the orogenic loading, or propagated southwards into the supercontinent from the divergent Tethyan margin of Gondwana. Superimposed on the tectonic control of basin development, climatic fluctuations also left a mark on the stratigraphic record, providing a common thread that links the sedimentary fills of all the Karoo basins, even those formed under different tectonic regimes. As a general trend, the climate changed from cold and semiarid during the Late Carboniferous to Early Permian interval, to warmer and eventually hot, with fluctuating precipitation during the rest of Karoo time.

The overall similarity of the Karoo succession in all of the SCA extensional basins has been recognised for well over half a century (e.g. Quennell et al., 1956). This is because their development was controlled by similar external (allocyclic) forces, namely related tectonism and climate (Catuneanu et al., 2005). The correlation of these various basins and sub-basins is covered in detail in Cairncross (2001), Johnson et al. (1996) and Catuneanu et al. (2005) and the interested reader is referred to these publications. Generally the Karoo successions of the rift basins exhibits five depositional sequences, each commencing with a coarse-grained lithotype at the base. This succession is exemplified by the fill of the Ruhuhu Basin in southern Tanzania (Figure 3).

North of the Main Karoo Basin the tectonic styles of the various coalfields in South Africa are different, being more similar to all the other basins and sub-basins of SCA. These two different basinal settings in South Africa (distal foreland versus extensional rift) host two very different types of coals, namely multiple seam type and thick interbedded seam type (Snyman, 1998, SANS 10320, 2004). These two different coal deposit types in South Africa are therefore described below first, to enable comparison with those in the rest of SCA.

\section{South Africa}

Coal was first mined on a commercial basis in South Africa in 1857 (from the Molteno Coalfield) and the country is currently the $6^{\text {th }}$ largest coal producer in the world, being by far the largest producer in Africa at 333.6 Million tonnes (Mt) in 2014. South Africa was one of the first countries in the world to use electricity on a commercial basis (Kimberley had electric street lights before London) and presently Eskom (www.eskom.co.za), the state-owned national electricity supply utility, generates over $90 \%$ of the country's electricity. South Africa is also the only country in the world that operates commercial, coal to liquids, synfuel plants. In addition to the extensive use of coal in the domestic economy, about $28 \%$ of South Africa's production is exported, mainly through the Richards Bay Coal Terminal, making South Africa the $4^{\text {th }}$ largest coal exporting country in the world.

Most authors accept that within South Africa 19 coalfields (Figure 4) may be defined based on variations in sedimentation, origin, formation, distribution and quality of the coals. These variations are in turn related to specific conditions of deposition and the local tectonic

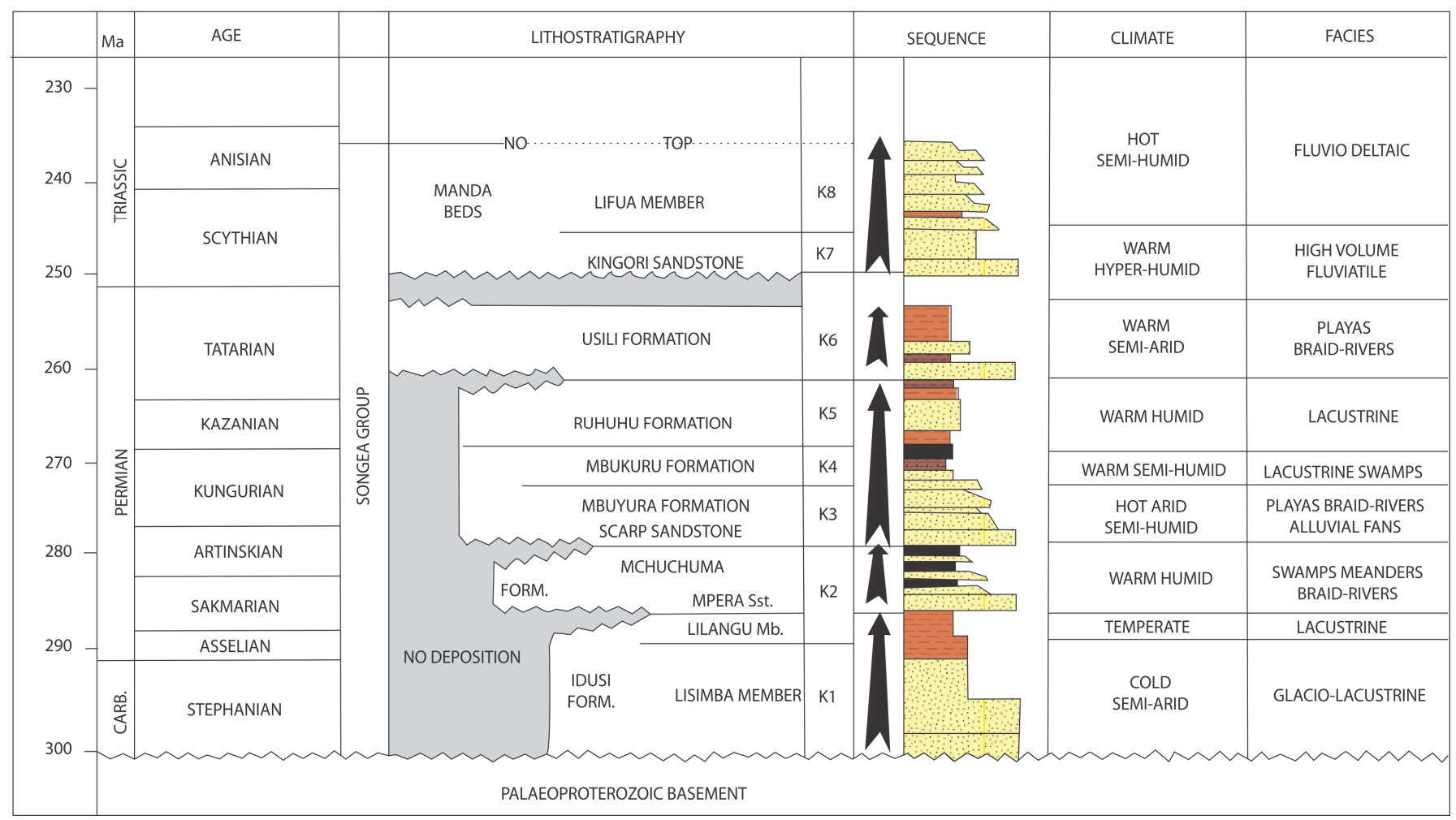

Figure 3: Stratigraphic table of the Songea Group as established for the Ruhuhu Basin in southern Tanzania. The general sedimentary fill, ages and climate change is however representative of all the depositional sequences of the rift related south-central Karoo basins. Symbols K1 to K8 identify the old informal stratigraphic scheme, which is still largely applicable (Modified after Catuneanu et al., 2005). Coal seams occur in the K2, $\mathrm{K} 3$ and $\mathrm{K} 4$ equivalents. 


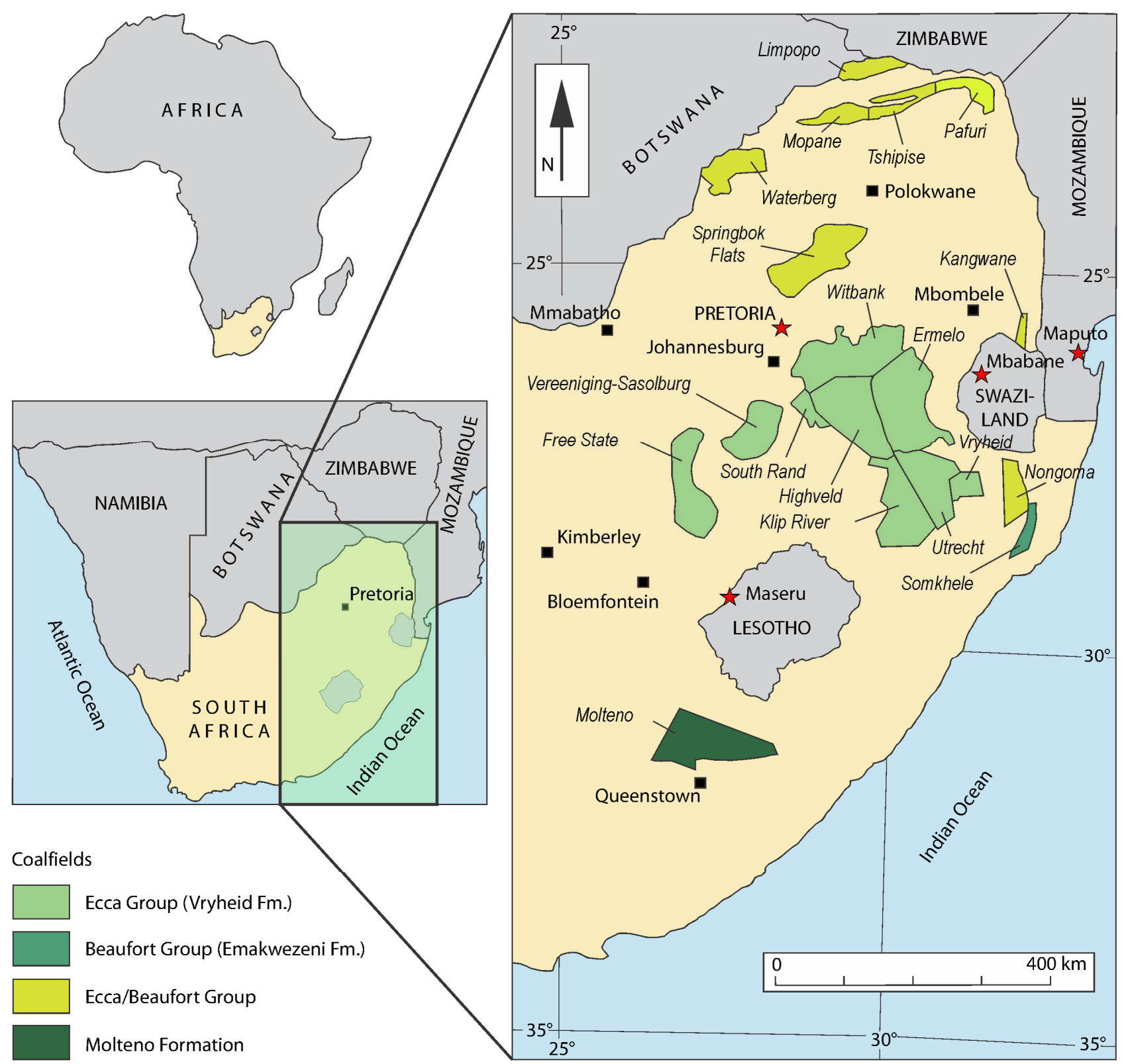

Figure 4: Map showing the coalfields of South Africa. (Variously modified after Snyman, 1998).

history of each area (Catuneanu et al., 2002). A detailed assessment of all 19 of these coalfields has recently been published (Hancox and Götz, 2014) and the interested reader is referred to this work.

The first type of coal deposit, referred to as multiple seam deposits (SANS 10320; 2004) are typified by the coals of the Central Basin, including the Witbank, Highveld and Ermelo coalfields (Figure 4). Of these, the Witbank Coalfield is probably the best known, and as such is used here as an example of this deposit type.

\section{Witbank Coalfield}

The history of commercial exploration in the Witbank Coalfield goes back over 125 years and this coalfield is still one of the most important in South Africa, supplying more than $50 \%$ of the country's saleable coal. The coalfield is also host to many of the major minemouth coal-fired power stations in South Africa.

The general geology of the Witbank Coalfield has been extensively studied by numerous previous authors (e.g. Le Blanc Smith and Eriksson, 1979; Le Blanc Smith 1980a, b; Cairncross, 1980; Winter, 1985; Cairncross, 1986; Cairncross and Cadle, 1988a, b; Holland et al., 1989; Grodner, 2002; Grodner and Cairncross, 2003; and Uys, 2007). The basement of the Witbank Coalfield changes dramatically from west to east, being variously formed by Witwatersrand Supergroup metaquartzites, Transvaal Supergroup dolomites, metaquartzites and metavolcanics, and granites, gabbros and norites of the Bushveld Complex. The changing nature of the basement is one of the major controls on the nature of the lower part of the sedimentary fill and contained coals.

Coal in the Witbank Coalfield is hosted in rocks of the Vryheid Formation (Ecca Group). The coal seams are mainly flat lying to gently undulating, with a very gentle $\left(1-3^{\circ}\right)$ regional dip to the south Five individual seams are usually recognised (Figure 5) associated with various depositional sequences. Of these the No.2, 4 and 5 seams are the most economically important. 


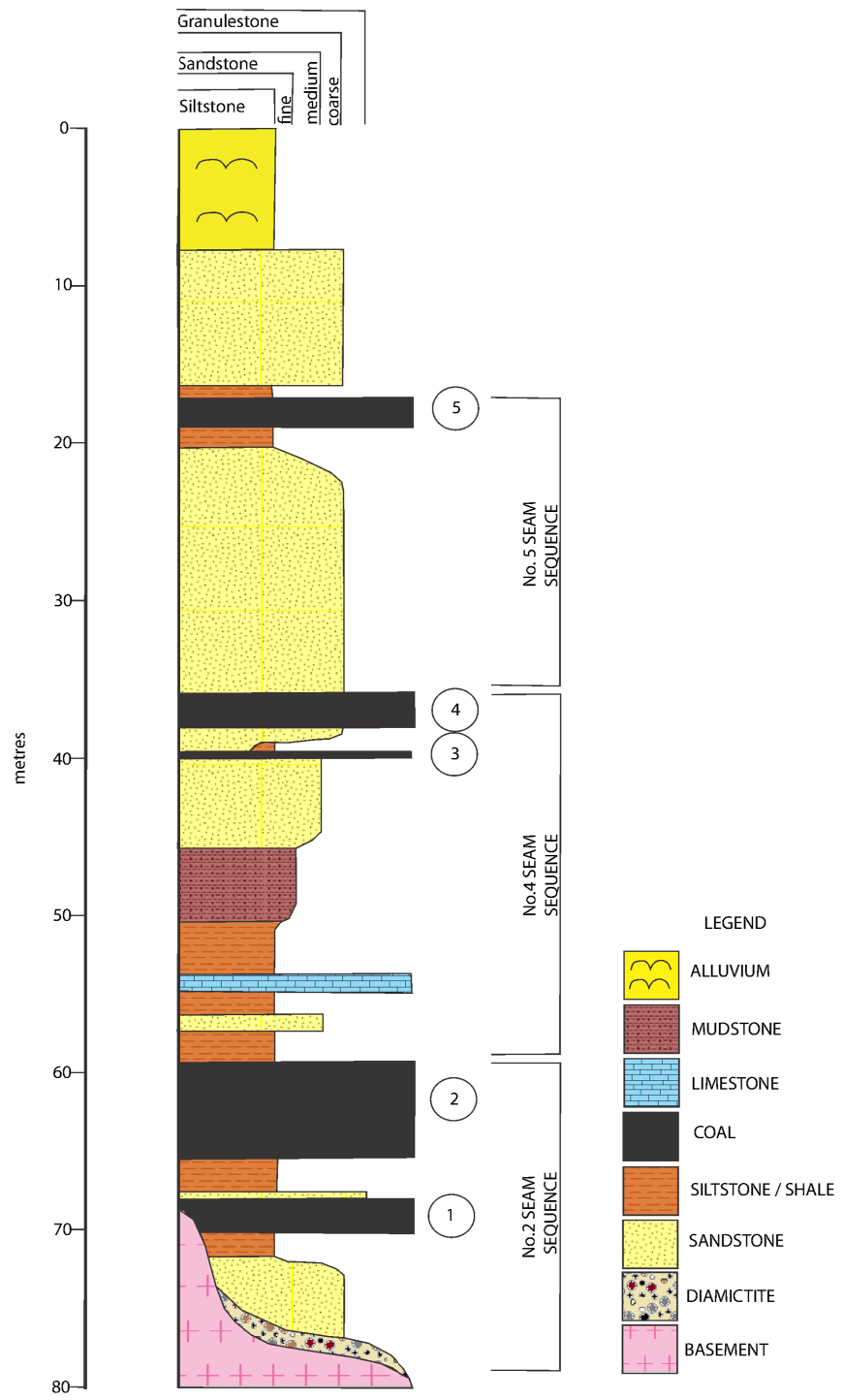

Figure 5: The generalised stratigraphy and depositional sequence of the Witbank Coalfield. Individual coal seams are shown with their corresponding numbers in circles. After Cairncross and Cadle (1988).

The No.2 Seam accounts for approximately $70 \%$ of the coal resources in the Witbank Coalfield and contains some of the best quality coal. The seam averages $6.5 \mathrm{~m}$ in thickness in the central part of the coalfield and thins to approximately $3 \mathrm{~m}$ towards the west and east (Snyman, 1998). Given the high degree of variability exhibited by the No. 2 Seam both spatially and temporally, it is difficult to present an average set of qualities for the seam. This variability is enhanced in the western sector where dolerites often devolatilise the seam. Technical reports for new projects in the western sector show the CVs for the No. 2 Seam to vary from 3.0 MJ/kg to $24.7 \mathrm{MJ} / \mathrm{kg}$, Ash from $22 \%$ to over $40 \%$, VM from $12 \%$ to $25 \%$, DAFVOLs varying from $13.5 \%$ to $43 \%$, and TS between lows of $0.5 \%$ and highs of over $10 \%$ (Hancox and Götz, 2014).

The overlying No.4 Seam accounts for approximately $25 \%$ of the coal resources in the Witbank Coalfield. The seam varies in thickness from approximately $2.5 \mathrm{~m}$ in the central Witbank area to $6.5 \mathrm{~m}$ elsewhere. The No. 4 Seam usually contains dull to dull lustrous coal that is used predominantly as a local power station feedstock. As for the No. 2 Seam the qualities of the No. 4 Seam across the Witbank Coalfield are highly variable. In the western sector of the Witbank Coalfield the raw CV for the No. 4 Seam varies from $4.0 \mathrm{MJ} / \mathrm{kg}$ to $25.81 \mathrm{MJ} / \mathrm{kg}$, with the DAFVOL percentages varying from $14.3 \%$ to $40.2 \%$ dependent on the proximity of dolerites (Hancox and Götz, 2014).

The No.5 Seam has been extensively eroded over large areas of the Witbank Coalfield, but where present is between $0.5 \mathrm{~m}$ and $2 \mathrm{~m}$ thick. It consists of mixed, mainly bright, banded coal with thin clastic partings in a few localities, and is generally a high quality (low Ash \% and high FC \%), low phosphorus coal, which is mainly marketed as a metallurgical product.

Jurassic aged dolerite dykes and sills are common in the Witbank Coalfield and are often positioned below, within and above the coal bearing interval. These intrusions tend to influence the stratigraphy and coal qualities in places, and mapping of their occurrences is critical for mine planning purposes.

SANS 10320 (2004) also recognises a second coal deposit type (thick interbedded seam deposit type) in South Africa, a style typified by the upper coal deposits of the Waterberg Coalfield.

\section{Waterberg Coalfield}

The Waterberg Coalfield (Figure 4) contains between 40-50\% of South Africa's remaining coal resources and is considered to be the last major coal deposit in the country. The coalfield is currently home to Eskom's Matimba Power Station, which at an installed capacity of 3,990 Megawatts (MW) is the largest direct dry cooling power station in the world. Construction is also well advanced on Medupi, a second dry-cooled, base load station, that when completed is to have six boilers each powering an $800 \mathrm{MW}$ turbine, producing $4,800 \mathrm{MW}$ of power, which would then surpass Matimba as the largest in the world.

Geologically the Waterberg Coalfield occurs in the fault-bounded Ellisras sub-basin, considered to be an embayment of the much larger Kalahari Basin that underlies a vast area of Botswana. This sub-basin is variously considered as a half-graben (Fourie et al., 2009) or graben structure (Sullivan et al., 2013). The basement to the basin is formed by Palaeoproterozoic metaconglomerates and metaquartzites of the Waterberg Group and Transvaal Supergroup, and/or basic rocks of the Bushveld Complex (Johnson et al., 1996). These are unconformably overlain by sedimentary rocks which are the equivalent of the Dwyka, Ecca, Beaufort and Stormberg groups in the Main Karoo Basin (Beukes et al., 1991; Faure et al., 1996).

Coal is hosted in two different levels of the Ecca Group. The lower coal seams, zones 1, 2, 3 and 4A (Figure 6), are predominantly dull coals that are mainly used for power generation. They are hosted in a $55 \mathrm{~m}$ thick package of the Vryheid Formation and are mainly sandstone hosted, being similar in nature to those described above for the Witbank Coalfield.

The overlying Grootegeluk Formation is between $70-90$ m thick and hosts the thick interbedded coal deposit type coals (zones 5-11 in Figure 6) (Faure et al., 1996; Dreyer, 2011). This style of interbedded (or bar-code) coal is also known from a number of the other coalfields in the north of South Africa, as well as from other SCA coalfields including Botswana, Zambia and Mozambique. These interbedded coal deposits all require beneficiation and some yield float fractions that may have metallurgical properties.

Little published information exists regarding the overall coal 


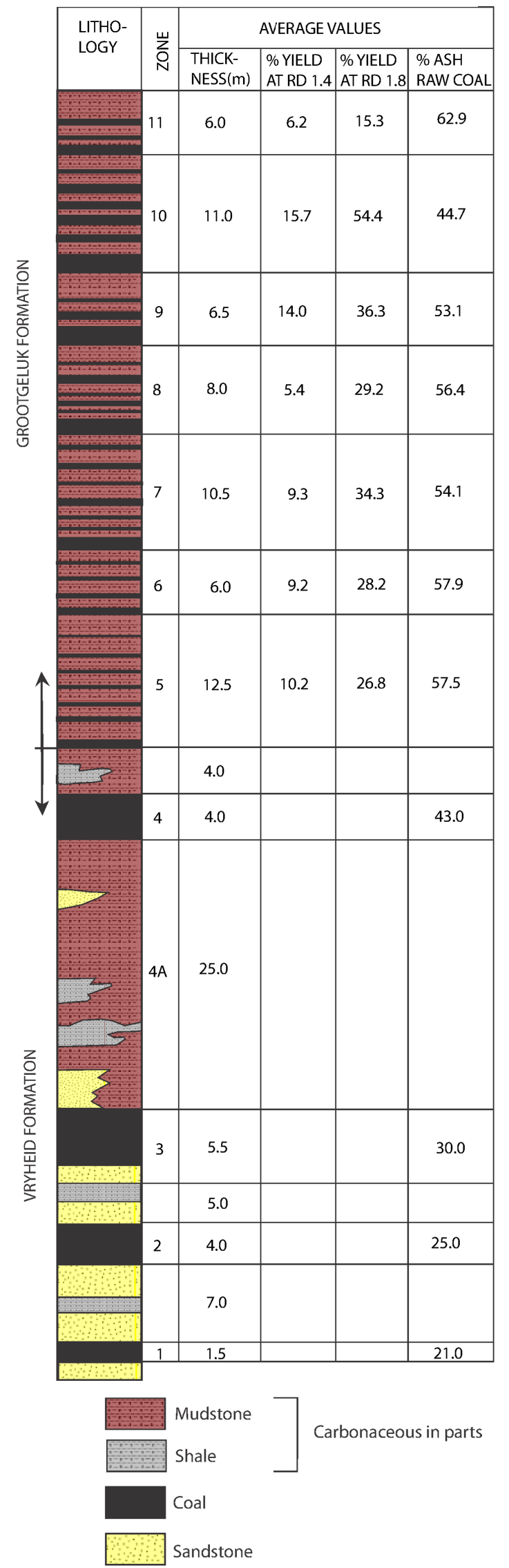

Figure 6: Stratigraphic column of the geology of the coal-bearing sequences of the Waterberg Coalfield showing the nature and coal qualities of the eleven coal zones (from Hancox and Götz, 2014). qualities of the Waterberg Coalfield and it is usually assumed that the qualities encountered at Grootegeluk Mine are potentially representative of the entire coalfield (Faure et al., 1996; and Dreyer, 2011). At Grootegeluk the qualities in zones 5-11 (Figure 6) are broadly similar to one another, with the primary wash of these zones yielding a blend semi-soft coking coal of around $10.3 \%$ Ash content. The secondary wash produces a middling product of approximately $35 \%$ Ash content, which is suitable for power generation. Average yields for a 1.4 and 1.8 Relative Density (RD) for the upper seven coal zones are provided in Figure 6.

\section{South Africa's Coal Resources and Reserves}

The first official estimate of South Africa's coal reserves was made in 1913 as a contribution to the Twelfth International Geological Congress, which was held in Canada that year. At this time the Department of Mines submitted a figure of 56.25 billion metric tonnes (Gt) for South Africa. De Jager et al. (1983) provided a table of recoverable reserves by coalfield, which gave a total reserve of 59.24 Gt. These were compiled during 1982 using information provided by all the coal mining companies. The most current report is that of Bredell (1987) in which he estimated South Africa's coal reserves as $55 \mathrm{Gt}$ (based on a $115 \mathrm{Gt}$ resource base). Based on a reduction in this number for South Africa's Run of Mine (RoM) coal production figures since this time, Prevost (2015) lists South Africa's reserves at the end of 2015 as $32.15 \mathrm{Gt}$.

The most recent review of South Africa's coal resources and reserves was undertaken in 2012 by the Council for Geoscience. Unfortunately, whilst complete, this work has not been made publically available. Ryan (2014) however notes that the new reserve estimate is 66.7 Gt RoM, a $21 \%$ increase over the Bredell (1987) figures, even though some $7.5 \mathrm{Gt}$ of coal have been mined during the 24-year period between the two estimates. He notes that the change is due mainly to increased figures for the Waterberg, Tuli and Soutpansberg (Mopane, Tshipise and Pafuri) coalfields (Figure 4), following extensive exploration work in the intervening years.

\section{Botswana}

\section{Introduction}

Although coal has been known in Botswana since the early 1930s, and the country has recently been the focus of a lot of exploration activity, it presently still only has one producing mine (Debswana's Morupule Colliery; http://www.debswana.com), which supplies coal to the Morupule B Power Station, as well as to mining operations at Selebwi Phikwe and to the Sua Pan soda ash plants.

\section{History}

Systematic exploration began in 1948 when reconnaissance investigations were conducted by the newly founded Geological Survey in the then known coal areas of Morupule and Mmamabula (Green, 1957). Prospecting in the Morupule Coalfield area was continued by the Geological Survey in 1959, when a small area along the eastern boundary of the coalfield was investigated. The Anglo American Corporation explored the eastern part of the Morupule area in detail in the late 1960s and confirmed the presence of coal of 
sufficient quantity and quality to support a mine. A mining lease was granted in 1966, leading to the development of the Morupule Colliery, which opened in 1973 and has been active ever since. Production was fairly limited until 1986, when the 132 MW mine-mouth Morupule Power Station was opened. In June of 2012 the Morupule Colliery Limited (MCL1) expansion project was commissioned in order to supply coal to the new 600 MW Morupule B Power Station, the first two units of which came online in 2013. The mine's capacity increased from $1 \mathrm{Mt}$ per annum (Mtpa) to $3.2 \mathrm{Mtpa}$ following the expansion.

\section{General Geology}

Geologically the Kalahari Basin underlies at least $60 \%$ of the country (Figure 2). As for the rest of SCA, the coal deposits are hosted in rocks of the Karoo Supergroup, which have been described by Smith (1984), Green et al. (1980) and more recently Modie (2007) and Segwabe (2008). Potentially exploitable areas for coal in Botswana are centred on the eastern and south-western flanks of the Kalahari-Karoo basin. Currently twelve coalfields are recognised
(Figure 7), including the fairly well-known Morupule, Mmamabula, Dukwe (or Dukwi), Foley and Serule coalfields.

\section{Coal Seams and Qualities}

In the Morupule Coalfield the coal bearing Morupule Formation (Figure 8) consists of an approximately $60 \mathrm{~m}$ thick sequence of carbonaceous fines and coals, with locally developed sandstone. Coal is also hosted in the overlying Serowe Formation.

Three seams with economic potential exist within the Morupule Formation. These are the Morupule Main, No.2 and Lotsane seams (A, B and C). The lowermost, Morupule Main Seam, is the target for the underground operations at the Morupule Mine, although coal is also mined from the No.2 Seam. The Morupule Main Seam is persistent over a large area of the coalfield and varies in thickness from only $1.0 \mathrm{~m}$ (in the northern and southern limits of the Morupule mine area), to between $6.5 \mathrm{~m}$ and $9.5 \mathrm{~m}$ elsewhere. The coal is normally considered to be sub-bituminous in rank. Cairncross (2001) notes the following qualities for the Morupule Main Seam: Ash 21.1\%; CV 24.4 MJ/kg; VM 24.3\% and TS 1.44\%. Segwabe (2008) lists

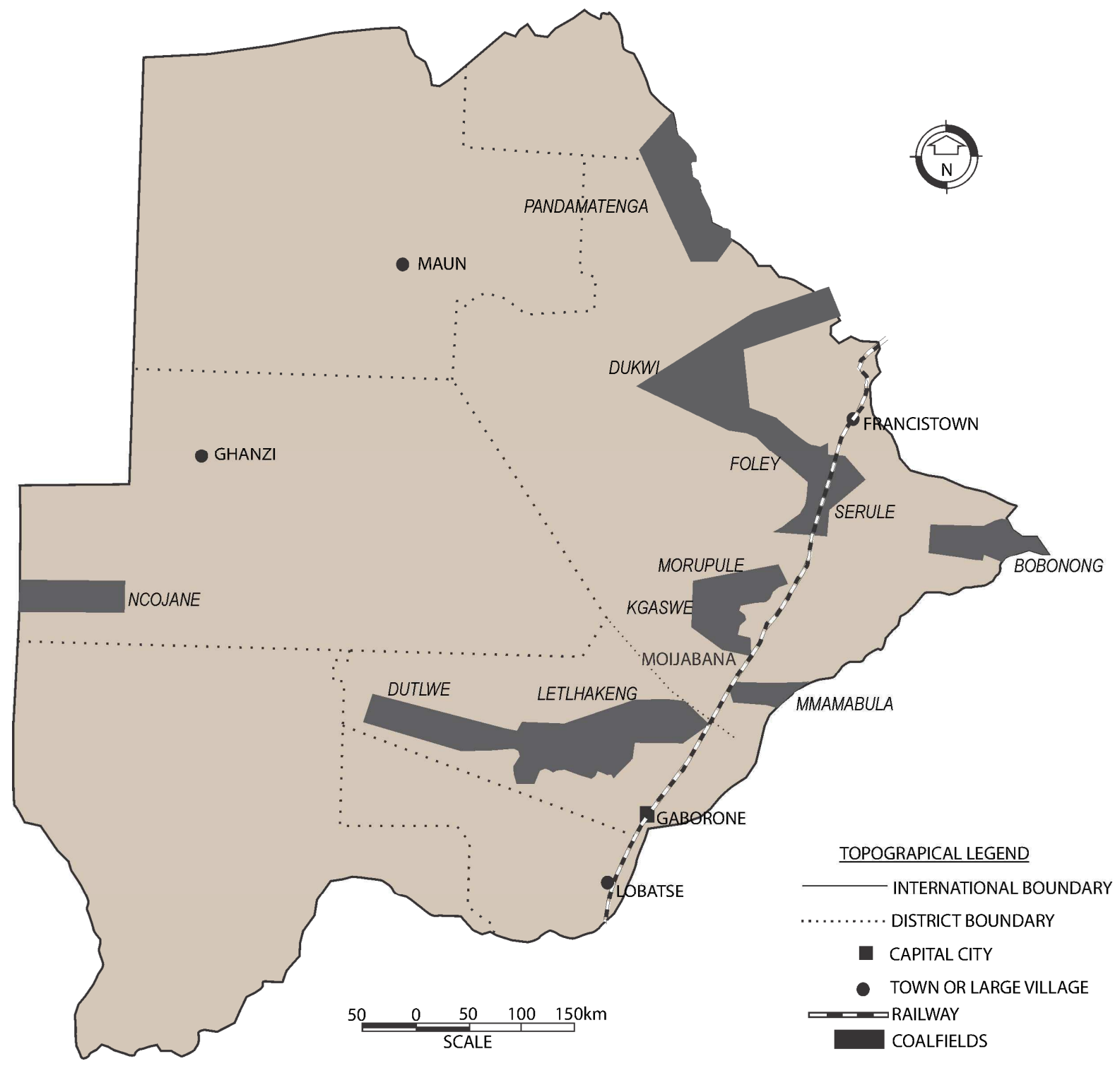

Figure 7: Map showing the various coalfields of Botswana (From Chatupa, 1991). 
SOUTHEAST CENTRAL KALAHARI SUB BASIN

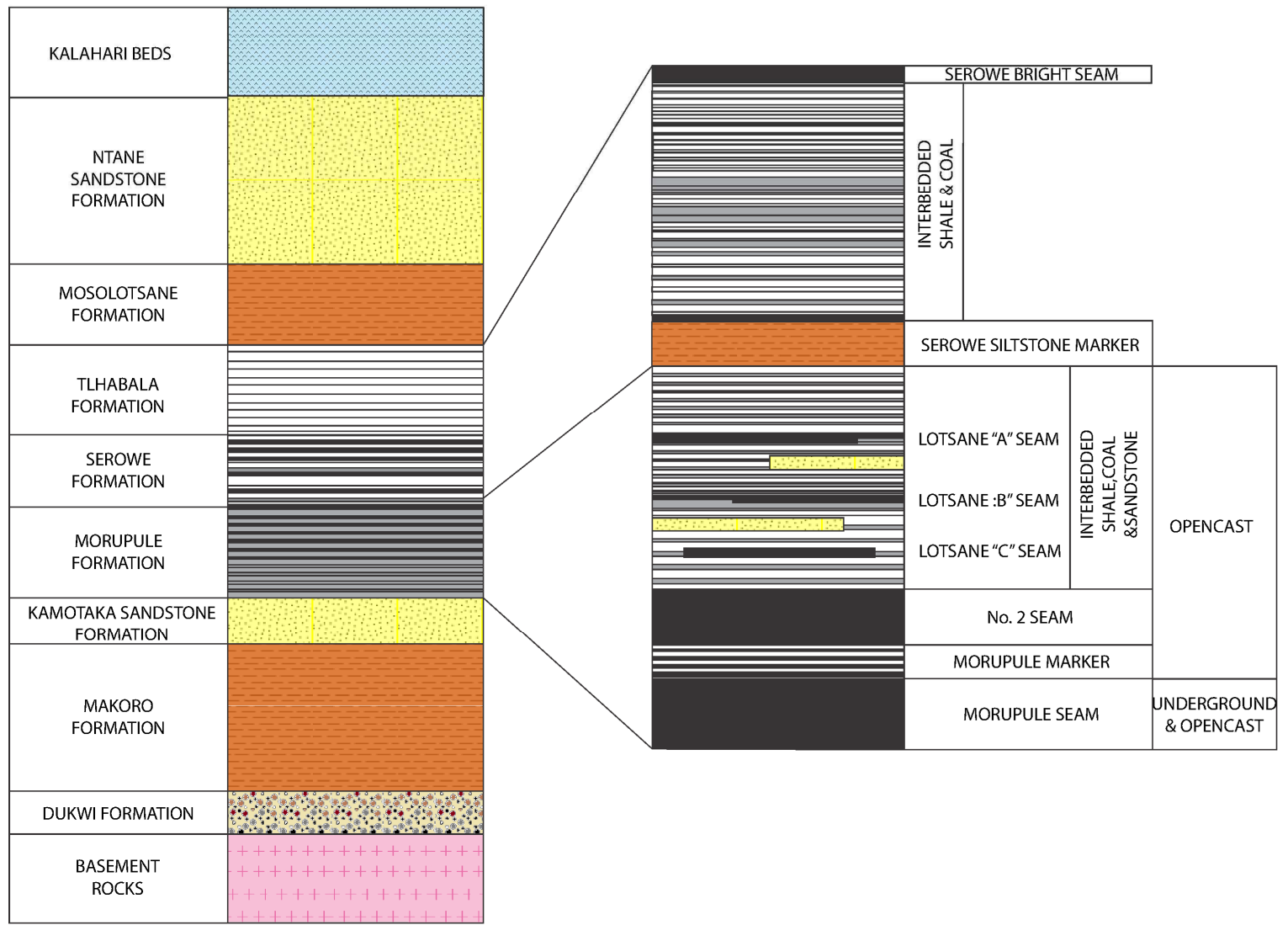

MORUPULE AREA

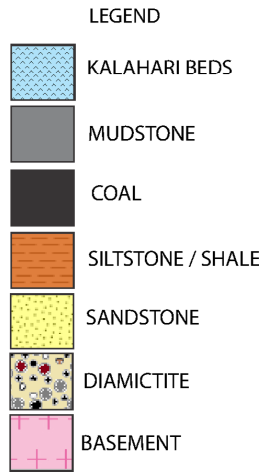

Figure 8: Stratigraphy of the Morupule Coalfield showing the potential for opencast and underground operations. Fm $=$ Formation (From Vergeer, 2010).

Ash of $25.4 \%, \mathrm{CV}$ of $23.08 \mathrm{MJ} / \mathrm{kg}$, TS of $1.52 \%$ and $\mathrm{VM}$ of $24.3 \%$ for the Morupule Main (quoting Clark et al., 1986 and Bennett, 1989 as his sources). Even though suitable for use as power station fuel, the coal produced by Morupule is of low quality, with relatively high levels of Ash and TS, which make it unsuitable for other purposes without beneficiation.

Some 7-10 m above the Morupule Main Seam, a carbonaceous sequence is present, the Morupule Marker, which locally contains poor quality coals. Although these coals are in places of mineable thickness, their patchy distribution and low quality do not render them of current economic interest.

The Lotsane Seam lies some 30-60 m above the Morupule Main Seam. It varies in thickness from 0.6-4.5 $\mathrm{m}$ and the proportion of coal and interbedded waste parting varies greatly. It is a mixed, mainly bright coal with a high Ash content, resulting in a lower CV raw coal than that of the Morupule Main Seam. Segwabe (2008) lists an Ash of $36.3 \%, \mathrm{CV}$ of $19.59 \mathrm{MJ} / \mathrm{kg}$; and TS of $2.35 \%$ for the Lotsane Seam.

The overlying Serowe Formation (Figure 8) consists of a lower, laterally persistent siltstone marker horizon, which is overlain by some $30 \mathrm{~m}$ of carbonaceous mudstone, siltstone and coal. The coals in the Serowe Formation, for the most part are poorly developed, but near the top of the formation the Serowe Bright Seam contains coal of possible economic importance. The Serowe Bright Seam averages $1.8 \mathrm{~m}$ in thickness and comprises two or three bands of mainly bright coal separated by thin, laterally extensive, mudstone horizons.
Although the CV of this coal is similar to that of the Morupule Main Seam (and has a high volatile content), it also has a high sulphur content and therefore is less attractive for the production of thermal coal. Segwabe (2008) lists an Ash of $32.3 \%$, CV of $20.73 \mathrm{MJ} / \mathrm{kg}$; and TS of $6.45 \%$ for the Serowe Bright seams.

\section{Coal Resources}

The official figures for Botswana put the resources at a massive $212 \mathrm{Gt}$ (Chatupa, 1991). These figures have however been challenged on a number of grounds by various people (e.g. Meyer, 2015). Whilst it is therefore difficult to properly quantify Botswana's coal resource base, it is probably in the order of tens of billions of tonnes. The actual resource base has been better defined by the extensive recent exploration, but this has not yet been compiled by the Botswanan Geological Survey and is not freely publicly available. Published figures by exploration companies indicate compliant resources in the order of $60 \mathrm{Gt}$ Gross Tonnes in situ (GTIS; Golding, 2015). The coals of the Morupule Coalfield account for around $10 \mathrm{Gt}$, with those of the Mmamabula Coalfield being the largest at $23.3 \mathrm{Gt}$.

\section{Zimbabwe}

\section{Introduction}

As with Botswana, Zimbabwe has a number of geographically 
separate coalfields (Figure 9) and the country has large coal resources, particularly in the northwestern and southern regions. Only one of these, the Hwange Coalfield, has been exploited to any meaningful extent, with very limited coal production also coming from the Sengwa Basin in the nortwwest as well as the Tuli and Save basins in the south. Coal production in 2013 was only $3.6 \mathrm{Mt}$, being around $1 \%$ of that of South Africa.

Some 34 coal occurrences and coalfields are recognised, with both coking (e.g. Hwange in the Mlibizi Basin and Bubye in the Save Basin) and thermal (e.g. at Hwange and in the Sengwa Basin) coal present. Coal is used for power generation as well as for the curing of tobacco, and the production of coke. Over $90 \%$ of the coal produced in the country is supplied to the domestic markets. Export revenues come from supply to the DRC, Zambia, Tanzania, Botswana and India.

There are presently two main collieries operational in Zimbabwe, each producing in the region of 200-300,000 tonnes per month (tpm). For over a century the main producer was the Hwange Colliery Company Limited, and this deposit is critical to Zimbabwe's energy provision. Since 2010, Makomo Resources (http://www.makomo resources.com/) has been mining the Entuba section of the Hwange Coalfield. The company plans to build a $600 \mathrm{MW}$ power station to try and fill the current electricity short-fall.

\section{History}

The Hwange (then named Wankie) coalfield was discovered in 1893 by Albert Giese, a German geologist who was on a shooting and trading expedition (Lightfoot, 1914). He registered the first claims in the same year, which he then sold to the Mashonaland Agency Limited. In 1895 Giese pegged a further 400 square miles for the Mashonaland Agency. In 1897 an expedition led by a Mr Harvey thoroughly explored the area and during this time five shafts were sunk to test the coal from outcrop. In late 1900 further exploratory work was undertaken, with 15 shallow shafts sunk near the outcrop.

In 1901 the rights of the Mashonaland Agency Limited were assigned to the Wankie (Rhodesia) Coal, Railway and Exploration Company Limited and in the same year construction of the railway to the area from Bulawayo commenced. In August of 1901 a preliminary shaft (of what became known as the No.1 Colliery) was sunk near to the site of the main drift (incline), which finally reached coal in January of 1902. Underground development continued during 1902, with underground coal mining beginning in 1903. By 1910 coal production at the No.1 Colliery had reached 180,000 tonnes per annum (tpa).

In 1914 the Geological Survey of Southern Rhodesia put out a bulletin containing three papers which covered aspects of the coal resources at Wankie. The first of these was by Lightfoot (1914), who described the geology of the north-western part of the Wankie Coalfield. In this work he describes the history of the discovery, and the nature of the entire Karoo succession and the coal bearing stratigraphy. The second paper (Thompson, 1914) by the then General Manager of the Wankie Colliery, describes the methods adopted in mining the coal. The final of the three papers is by the then Director of the Geological Survey and discusses the coal resources of Rhodesia (Maufe, 1914).

By the 1920s and 1930s production had expanded to 4 Mtpa and increased demand led to the commissioning of the No.2 Colliery in

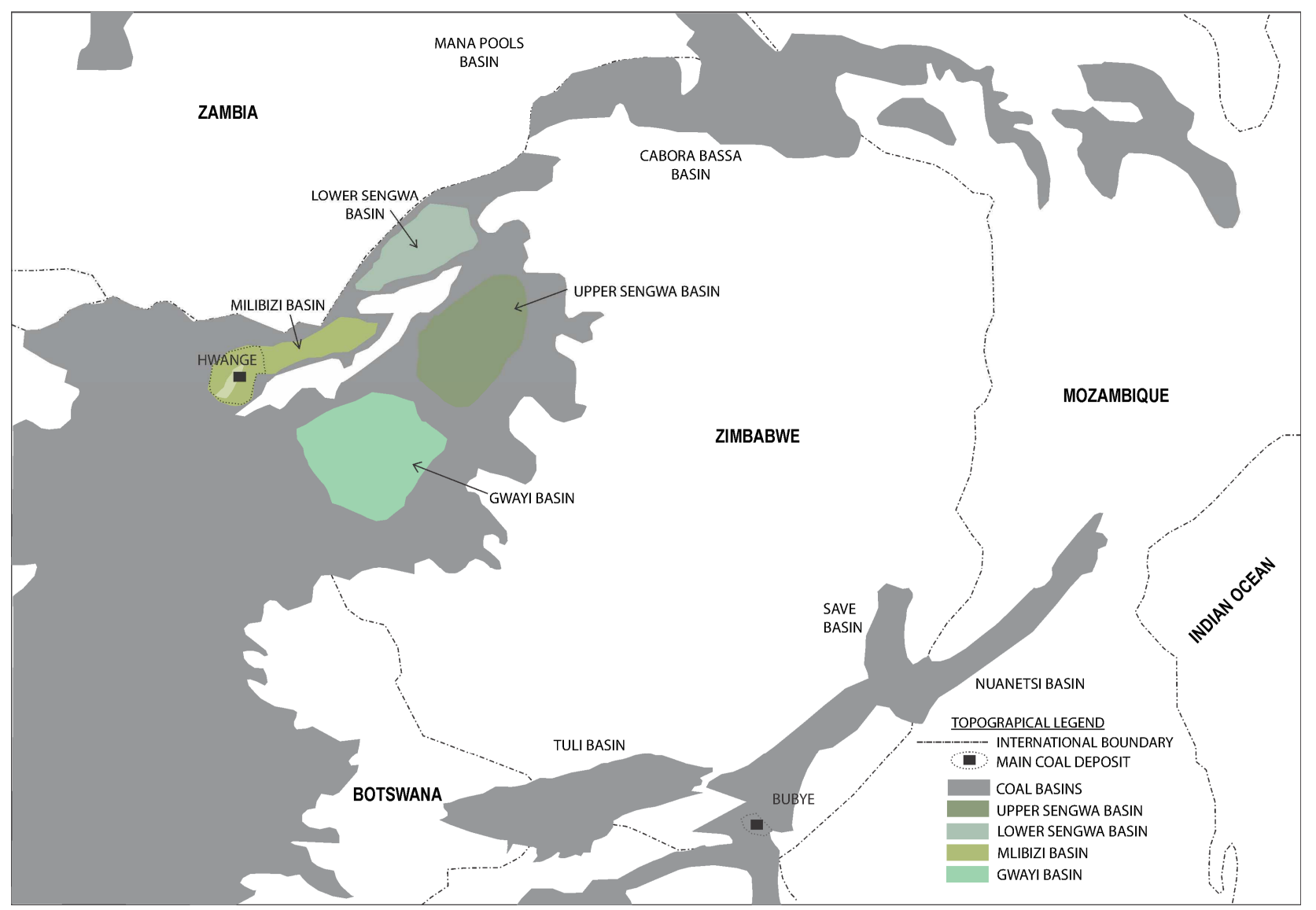

Figure 9: Coal bearing basins of Zimbabwe highlighting the positions of the northern basins. From: Maponga (2015). 
1927. After World War II the Anglo American Company took over the mines and opened up the No.3 Colliery in 1953. The No.1 Colliery was finally decommissioned in 1961 following the commissioning of Kariba Hydro Electric Power Plant, having produced some 60.3 Mt in its history (Matyanga, 2012). The No. 2 Colliery closed in 1972 following an explosion that claimed 472 lives. Matyanga (2012) notes that at the time of its closure it had produced around 83.5 Mt. This disaster focussed operation at surface and the mine produced principally by opencast methods thereafter.

A major boost to the operations came about in 1986/1987 with the commissioning of the 920 MW Hwange Thermal Power Station. This led to the commissioning of the main opencast mine, and the employment of a dragline to undertake the stripping required. Production reached a peak of 5.9 Mtpa in 1991. The No.3 Colliery remained in operation until 1999 , having produced $88.1 \mathrm{Mt}$ at the time of its closing. On the $19^{\text {th }}$ of June 2000 the name Wankie Colliery Company Limited was officially changed to Hwange Colliery Company Limited and by 2004 the colliery had produced some 222.06 Mt.

\section{General Geology}

Geologically the main coal resources in Zimbabwe are hosted in the lower part of the Karoo Supergroup equivalents, in two separate basins located on either side of the Zimbabwean Craton. The southern Save-Tuli (Limpopo) Basin (Figure 9) overlies the Limpopo Mobile Belt and is similar in many ways to the coalfields of northern South Africa, such as the Tuli (Limpopo) Coalfield (Figure 2 and 4). These deposits are severely faulted and intruded by igneous bodies, and have high Ash (\%) contents due to the intercalated mudrock (as per the Grootegeluk Formation hosted coals of the Waterberg Coalfield of South Africa, as described above).

The northern, Mid-Zambezi Basin overlies the Damara-Zambezi and Zambezi mobile belts. These deposits, which include the Hwange and Sengwa coalfields, are less affected by igneous intrusions and tectonism than those in the south and are relatively thicker and of better quality. A synthesis of the available data on the main coalfields in the Mid-Zambezi basin is provided in Thompson (1981) and Palloks (1984). In all coalfields only the basal seam is targeted. In the Hwange Coalfield it is known as the Main Seam.

\section{Coal Seams and Qualities}

The best known and documented seam in Zimbabwe is the Hwange Main Seam. This seam, which may be between 5-17 m thick, is the chief seam worked at the Hwange Colliery. It is well documented by Maponga (2015) who provides detailed seam analysis. In general the Ash (\%) and phosphorus contents increase with distance above the floor of the seam, whereas the VM and TS contents decrease. The lower part of the seam (known as the HCC sub-seam at Hwange) has a maximum $15 \%$ Ash and minimum $23.5 \% \mathrm{VM}$, TS of between $1-1.75 \%$ and is vitrinite rich. It is from this sub-seam that the hard coking coal is produced. The upper (HPS sub-seam) has a maximum 24\% Ash and is inertinite rich, being used for power generation.

\section{Coal Resources}

There are various resource estimates available for the coal resources of Zimbabwe and these vary widely. Duguid (1986) notes that in 1980 Zimbabwe's total in situ coal resources were 26.65 Gt. In 1989 the World Bank estimated about $20 \mathrm{Gt}$ of opencastable coal at a stripping ratio of up to 7 bank cubic metres per tonne $(\mathrm{bcm} / \mathrm{t})$ of coal. Barber (1988) estimated about $10 \mathrm{Gt}$ of opencastable coal at a stripping ratio of $3.5 \mathrm{bcm} / \mathrm{t}$ of coal. Matyanga (2012) documents the coal resources of Zimbabwe to be over $30 \mathrm{Gt}$ and estimates that the Lubimbi Coalfield, within the Gwayi Basin (Figure 9), alone hosts a GTIS resource of some $22 \mathrm{Gt}$, accounting for over $70 \%$ of the total known coal resources of Zimbabwe. The Hwange area (Milibizi Basin in Figure 9) coal resources are however the best known and documented. These include Hwange Colliery Company's Hwange (418 Mt) and Chaba (103 Mt) resource areas, the Western Areas resources (952 Mt), Makomo Resource's Entuba area (532 Mt); and Liberation Mining's Sinamatella area (96 Mt), for a total of $2.1 \mathrm{Gt}$.

\section{Zambia}

\section{Introduction}

Zambian Karoo aged coal deposits occur within the rift basins of the Mid-Zambezi, Luangwa, Luano-Lukusashi and Kafue valleys. The only active colliery in Zambia in 2015 was Maamba Colliery Limited's (http://www.maambacoal.com/) Maamba mine. This company is establishing a first phase, mine mouth, 300 MW Coal Fired Power Plant, which may be increased to 600 MW in a second phase, depending on the build-up of demand for power in the region.

In the Mid-Zambezi Valley three coal-bearing sub-basins are known (Figure 10), including the Nkandabwe Coalfield (hosting the suspended Collum Mine), the Siankondobo Coalfield (hosting the Maamba Colliery Limited operations) and the Mulungwa Coalfield, which is the focus of ongoing exploration.

\section{History}

Geological investigation of the Maamba coal deposit began in the 1960s following on an initial report by Gair (1959) and the regional work of Tavener-Smith $(1960,1962)$. The initial reconnaissance and mapping of the area was undertaken by the National Coal Board and Geological Survey of the then Federation of Rhodesia and Nyasaland. Accounts of this work are provided in Pagella and Drysdall (1966), Drysdall et al. (1967) and Denman and Money (1968). This work was followed up with a series of widely spaced boreholes drilled throughout the Siankondobo Coalfield, with further drilling concentrating on shallow coal in the areas of potential open pit workings.

By 1967 exploration at what was to become Maamba Colliery was underway by the Geological Survey Department of the Northern Rhodesia Government. Surface mining commenced in 1971 and early extraction exploited the outcrop and subcrop areas of thick coal development, focussing on the Kanzinze Basin of the Siankandobo Coalfield (Figure 10). Kanzinze was later abandoned when it became uneconomic due to the increased depth of the coal seams and concomitant increase in the required strip ratio. In 1992 a truck and shovel operation was started in the Izuma A basin. Mining then moved to the Izuma B open-pit, which was mined between 2001 and 2006, when the mine was placed on care and maintenance. Operations were re-started in 2010. 


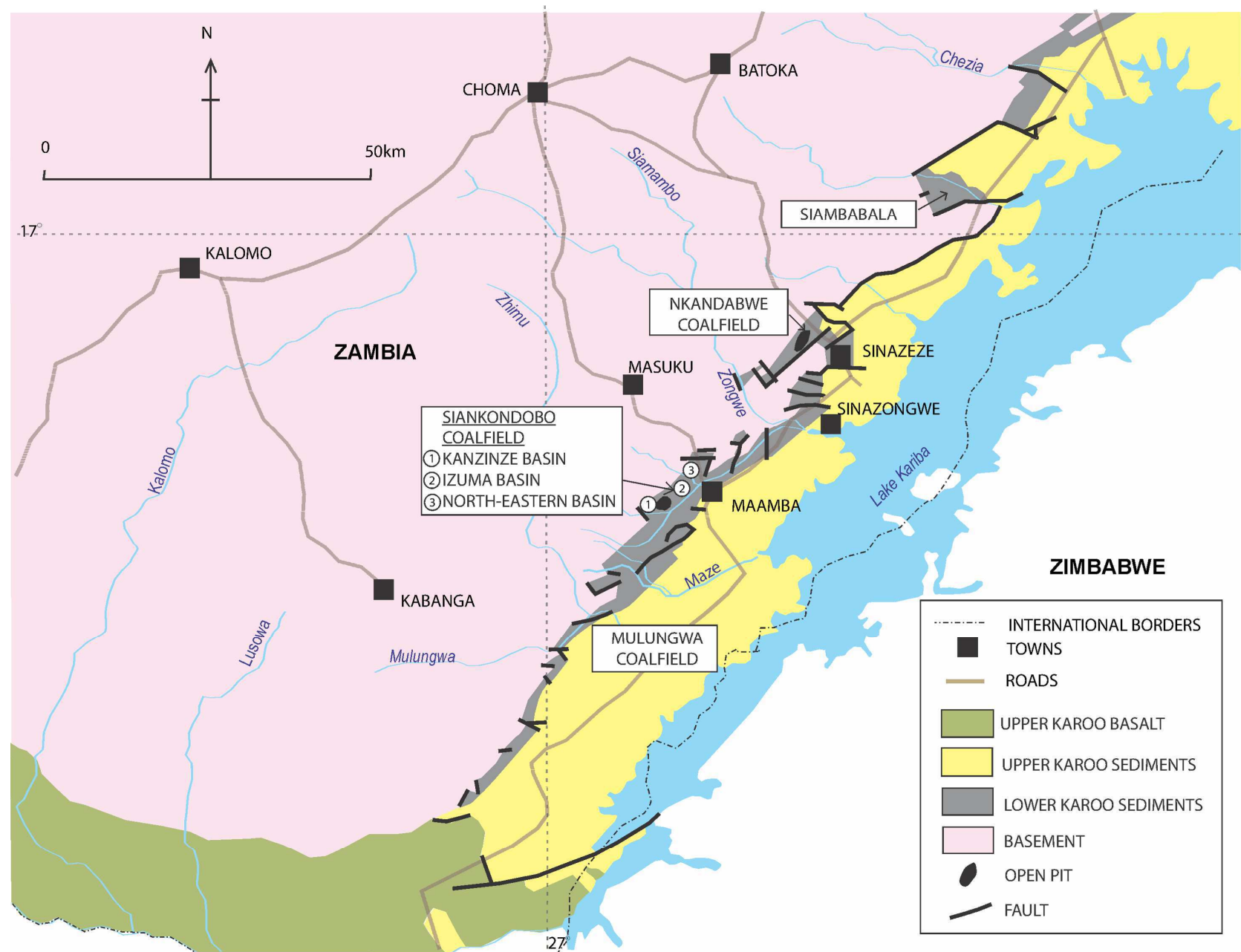

Figure 10: Geological map of south-eastern Zambia highlighting the three coal-bearing sub-basins in the Mid-Zambezi Valley. After Nyambe and Utting (1997).

\section{General Geology}

The Karoo Supergroup in the Mid-Zambezi Valley may be broadly divided into a lower and upper Karoo succession. The Lower Karoo succession (Figure 11) comprises a basal conglomerate, tillite and sandstone (the Siankondobo Sandstone Formation), which is unconformably overlain by conglomerate, coal, sandstone and carbonaceous siltstones and mudstones (the Gwembe Coal Formation) and finally fine grained lacustrine sediments of the Madumabisa Mudstone Formation. The Upper Karoo succession unconformably overlies the Madumabisa Mudstone Formation and comprises a series of arenaceous continental sedimentary rocks and overlying mudstones, capped by basalts of the Batoka Formation (Upper Karoo basalt in Figure 10).

Coal is restricted to the Gwembe Formation, which in the midZambezi Valley has a maximum thickness of $280 \mathrm{~m}$ (Nyambe and Utting, 1997; Nyambe, 1999) and consists mainly of carbonaceous mudstone and siltstone, with interbedded coal seams and sandstones. The Gwembe Coal Formation may be further informally sub-divided into a lower, middle and upper member. The lowermost Maamba Sandstone member is composed of coarse grained sandstones and granulestones, which are overlain by interbedded coals and siltstones and mudstones of the middle member. The middle coal facies member includes the economic Main Seam, which has thicknesses of between
5-12 m (Nyambe, 1999).

The major structural feature of this area is the northeast-southwest orientated Zambezi escarpment, which is formed by a major bounding fault that forms part of the Deka Fault zone (Hlatywayo, 1995). Numerous high angle normal faults also traverse the coalfields, with displacements documented as varying from 1-160 $\mathrm{m}$. The faulting is of two or more major ages, each with its own effect on the development of the coal.

\section{Coal Seams and Qualities}

Strangely, whilst Zimbabwe has decent metallurgical coals, its neighbour in the Mid-Zambezi Valley does not. Coals in the MidZambezi Valley of Zambia are bituminous hard black coal (with high Ash (\%) content). According to Bennett (1989) the coal at the Maamba Colliery is a medium quality, non-coking, thermal coal possessing fairly high inertinite content. Bennett (1989) further provides RoM quality data that shows Ash contents of up to $25 \%$, moisture contents in the order of $2 \%$ and TS values of between $1 \%$ and $4 \%$.

\section{Coal Resources}

There is very little publically available information concerning the coal resources in Zambia. At present, the only data available 


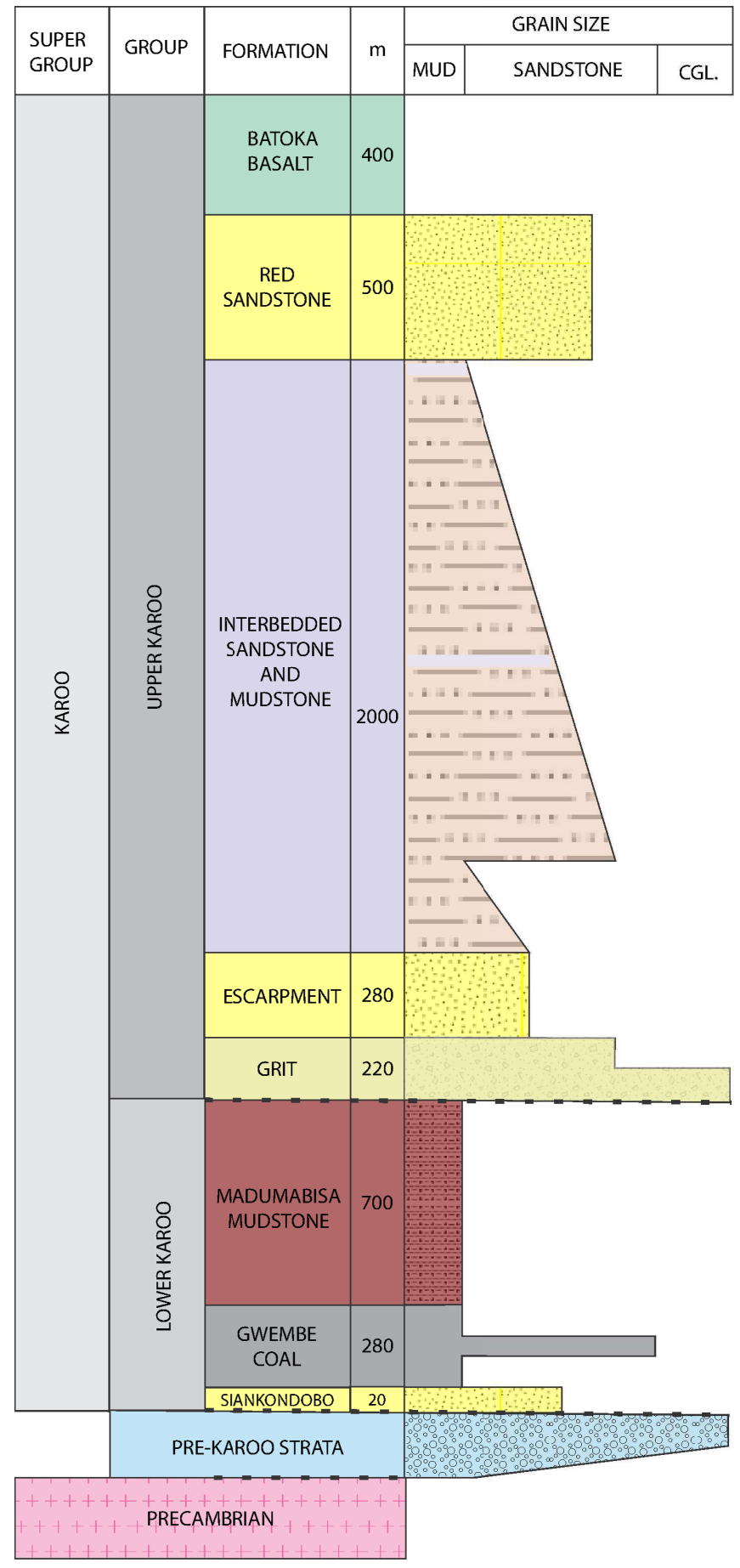

Figure 11: Generalised stratigraphy of the Karoo Supergroup in southern Zambia. From Mathisen and Roscoe (2012) based on a figure in Nyambe and Utting (1997).

pertains to the operations at Maamba Colliery. It is however the author's opinion that the coal resources for the Mid-Zambezi Valley presently stand at around $500 \mathrm{Mt}$, although this figure could increase significantly with ongoing exploration.

\section{Mozambique}

\section{Introduction}

The Mid-Zambezi Valley coal deposits continue into the western part of the Tete Province of Mozambique. Most of the coal bearing Karoo Supergroup equivalent deposits of Mozambique were laid down in an east-west trending, tectonically controlled basin that stretches over $350 \mathrm{~km}$, from Lake Cahora Bassa in the west, to the Malawi border in the east (Figure 12).

Whilst much exploration work has been undertaken in the past decade, in 2015 only three collieries were operating in Mozambique, these being Vale's (http://www.vale.com/) Moatize and ICVL's (http:/ /icvl.in/) Benga mine (both in the Moatize-Benga coalfield) and Jindal Steel and Power's (http://www.jindalsteelpower.com/) Chirodzi Mine in the Sanângoè-Mefídézi coalfield. In 2014 Mozambique exported $4.87 \mathrm{Mt}$ of mainly hard coking coal.

\section{History}

The history of coal discovery in Mozambique goes back to the artist/explorer Thomas Baines, who painted a coal outcrop on the banks of the Zambezi in the late 1850s. The first geological works on the coals of the Tete Province were undertaken by Richard Thornton (1859) a geologist on the Zambezi expedition under Dr David Livingstone and Guyot (Hatton and Fardell, 2011).

Commercial mining on a small scale commenced in the Moatize Coalfield in the early 1900s. For nearly a century this is where the Mozambique coal economy remained, until in late 2004 a consortium of companies headed by the Brazilian multinational Vale (http:// www.vale.com) won the right to develop the Moatize coal deposit. The allocation of the tender to Vale opened the way for other investors to stake positions in the Tete Province coalfields and so began a ten year exploration boom in the country.

\section{General Geology}

The geology of the Tete Province is dominated structurally by the Zambezi rift, which follows the fabric of the underlying Sanângoè Shear Zone in the Precambrian basement (Lächelt, 2004). Most authors believe that the positions of the major boundary faults to the various fault-bounded sub-basins (Figure 12) are strongly controlled by major Precambrian structures, particularly the Sanângoè Shear Zone.

The main Zambezi Basin may be further divided into a number of sub-basins (Figure 12) that are now disconnected due to Jurassic and Cretaceous extensional tectonics and subsequent erosion. From west to east these are variously termed the Chicôa-Mecúcoè (including the Mucanha-Vuzi sector), Sanângoè-Mefídézi, Moatize (or MoatizeBenga), Muarazi and Minjova sub-basins, with northwest and southeast extensions to Ncondezi (or N'condezi) and Mutarara (Vasconcelos, 2013). Because of the long extensional history and structural complexity, most of the coal seams (and strata) are generally inclined. Coal is presently mined only from the Sanângoè-Mefídézi and Moatize sub-basins.

In the early years of the new century the GTK (Geological Survey of Finland) Consortium (2006), re-mapped the Karoo Supergroup equivalents of the Tete Province at a 1:250,000 scale. The presently accepted (although unofficial) stratigraphic succession and nomenclature for these sub-basins in the Tete Province is presented below as Figure 13.

Mesozoic (Jurassic to Cretaceous) vertical crustal movements related to the break-up of Gondwana, including the separation of Africa from eastern Gondwana, created various rifts (grabens, half- 


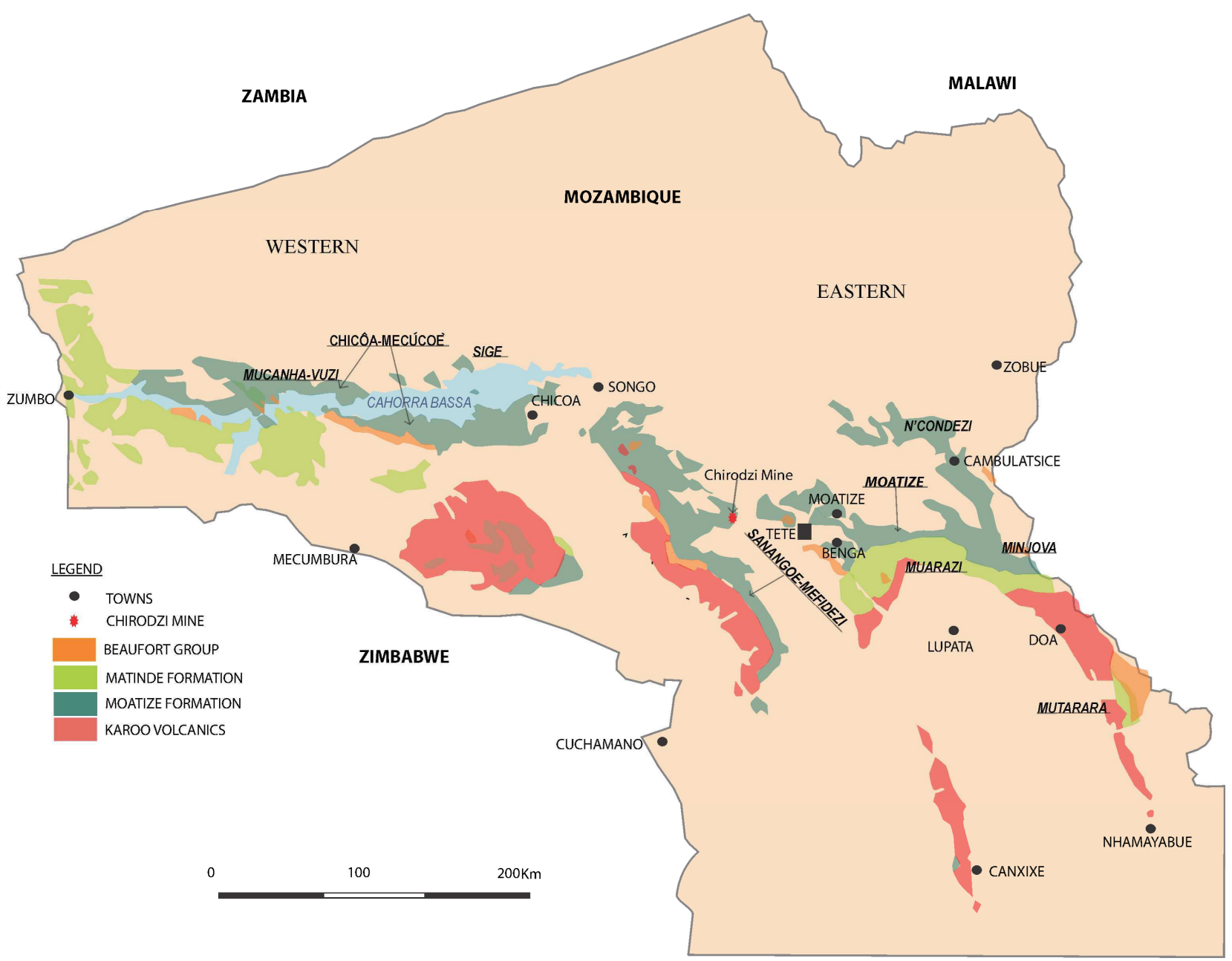

Figure 12: Map showing the sub-basins of the mid-Zambezi Valley. (From Vasconcelos, 2013). Dark green areas indicate outcrops of the Moatize Formation whereas light green denotes the Matinde Formation.

grabens and horsts). This has been overprinted by crustal doming in the Cenozoic, and rifting and volcanic activity associated with the East African Rift System. The Jurassic rifting event also allowed for the intrusion of various dolerite dykes and sills. In places dolerite intrusions have caused large volumes of coal to have been burnt or converted to low volatile lean bituminous or semi-anthracitic coals.

\section{Coal Seams and Qualities}

Coal is hosted in the Vúzi, Moatize and Matinde formations (Vasconcelos, 2000, 2013; Lloyd, 2015). Vúzi Formation coals tend to be sporadically developed and of poor quality. As currently defined, the Moatize Formation (formerly the Productive Series) unconformably overlies either Proterozoic basement or the Vúzi Formation and contains the main economically significant coal deposits. In the main Moatize coalfield the thickness of the Moatize Formation varies between $260-400 \mathrm{~m}$ and usually contains six coal seams (or coal zones), which are variously given names, letters or numbers as codes (Cairncross, 2001) (Figure 14). Due to the historic dominance of the Moatize sub-basin coalfield as a mining area, this stratigraphy has become the standard against which coal successions in other sub-basins are compared and correlated.

The coal seams in the Moatize sub-basin coalfield may generally be subdivided into two major types, those hosted in thick carbonaceous fines units (e.g. the Sousa (or Souza) Pinto and Chipanga seams) and those bound above and below by sandstones (e.g. the Intermedia, Grand Falaise and Andre seams) (Figure 14). Seams range in thickness from $0.5-40 \mathrm{~m}$ and typically consist of coal and finely interbedded coal and carbonaceous mudstone, with occasional thicker partings of siltstone. The coal itself is often described as bright with minor dull bands, due to the high content of vitrinite. The interburden thickness between the coal seams varies from 20-50 m. The main target seam for most present operations in the Moatize sub-basin coalfield is the Chipanga Seam, which may reach a thickness of up to $50 \mathrm{~m}$.

The Matinde Formation disconformably overlies the Moatize Formation and is the uppermost Karoo unit preserved over much of the Moatize sub-basin. The Formation generally consists of coarse cross-stratified sandstone, siltstone and mudstone, with variously developed coal seams, that are interpreted as having been deposited in fluvial sedimentary environments. It is reported to be up to $600 \mathrm{~m}$ thick in some areas of Mozambique (Vasconcelos, 2013). As for the Moatize Formation, the coal seams in the Matinde Formation may generally be subdivided into two major types; those bound above and below by sandstones (in the lower part) and those hosted in thick carbonaceous fines units (in the upper part of the Formation) (Lloyd, 2015).

Coals are generally of high Ash (40-70\%) and variable VM. Whilst selective underground mining was undertaken historically, all 


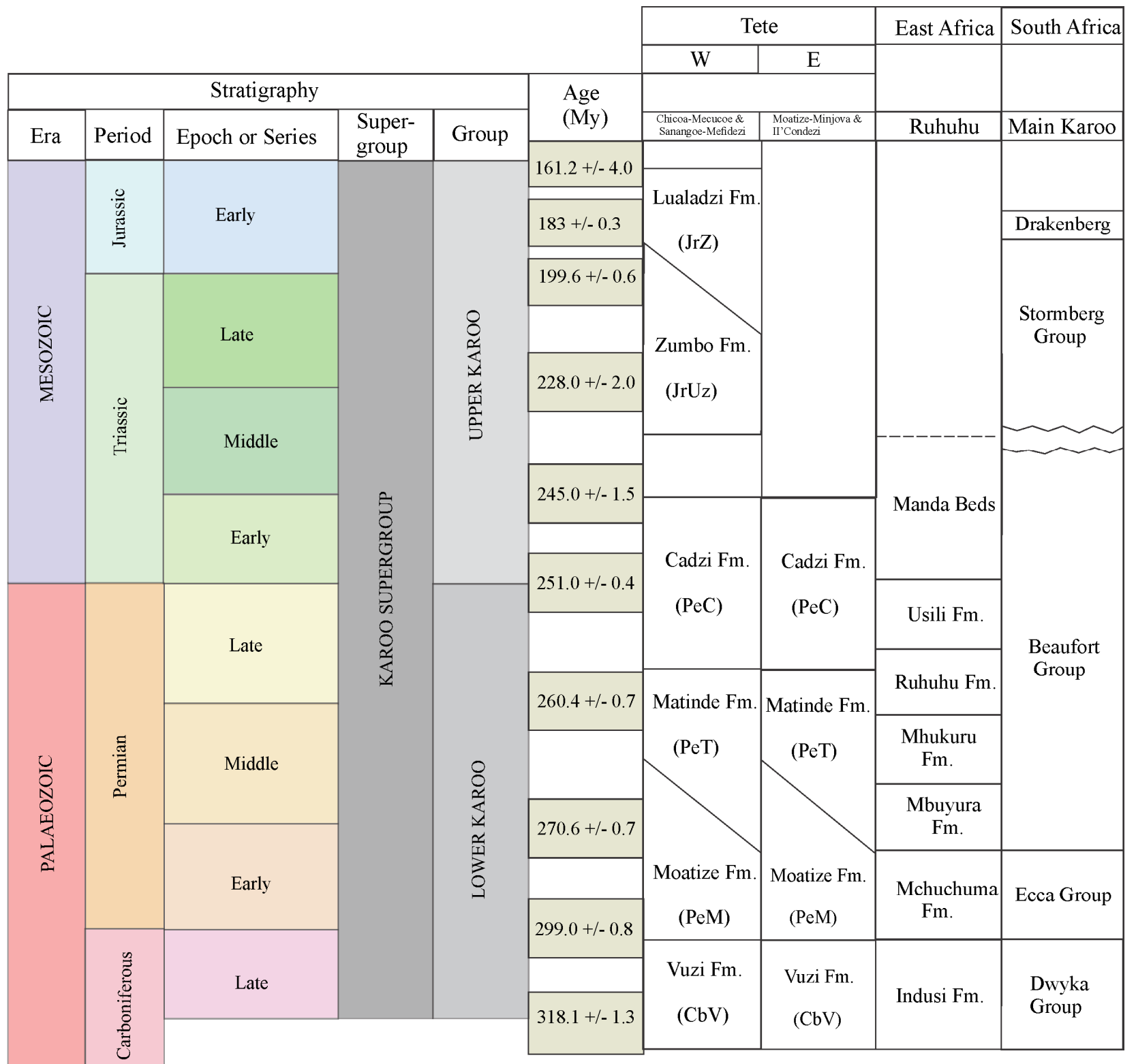

Figure 13: Stratigraphic nomenclature of the Karoo aged sequences in the Tete Province. Abbreviations in parenthesis refer to the various codes on the 1:1,000,000 geological map (Hartzer, 2008).

current operations extract the entire seam and beneficiation is required. Washed coal qualities vary dependent on the product generated, but generally a $10.5 \%$ Ash (coking) and $22-26 \%$ Ash (thermal) are produced, with yields dependent on the product mix and coalfield. Overall yields are usually in the region of $40-50 \%$ and of this the coking coal yield is typically around only $17-23 \%$ and the balance of between $20-25 \%$ is lower grade thermal coal.

\section{Coal Resources}

In 2013 the Mining Directorate of Mozambique compiled a table of compliant coal resources based on the information provided by the coal companies. This work showed a total of $25.4 \mathrm{Gt}$ of which $11.3 \mathrm{Gt}$ was in the Inferred Resource category, $10.5 \mathrm{Gt}$ in the Indicated category and 3.6 Gt in the Measured category. These numbers apply to 16 licenses, ten from the Moatize-Ncondézi-Mutarara sub-basins, two from the Sanângoè-Mefidéz sub-basin, three from the Mucanha-
Vuzi sub-basin and one from the northern Metangula basin (Vasconcelos, 2013).

\section{Malawi}

\section{Introduction}

Karoo aged successions containing coal are known from two distinct areas of Malawi, one in the south, which is a continuation of the coalfield of the eastern Tete Province, and one in the north, which is contiguous with the coal bearing basins of Tanzania (Figure 15). The country has never been a large producer of coal, with only small amounts being mined for the local markets. Domestic industrial demand for coal is estimated to be between 120,000-150,000 tpa and in 2013 the entire country's coal output was consumed internally by Malawi's brewing, cement, ethanol, sugar, tea, textile, and tobacco industries. 


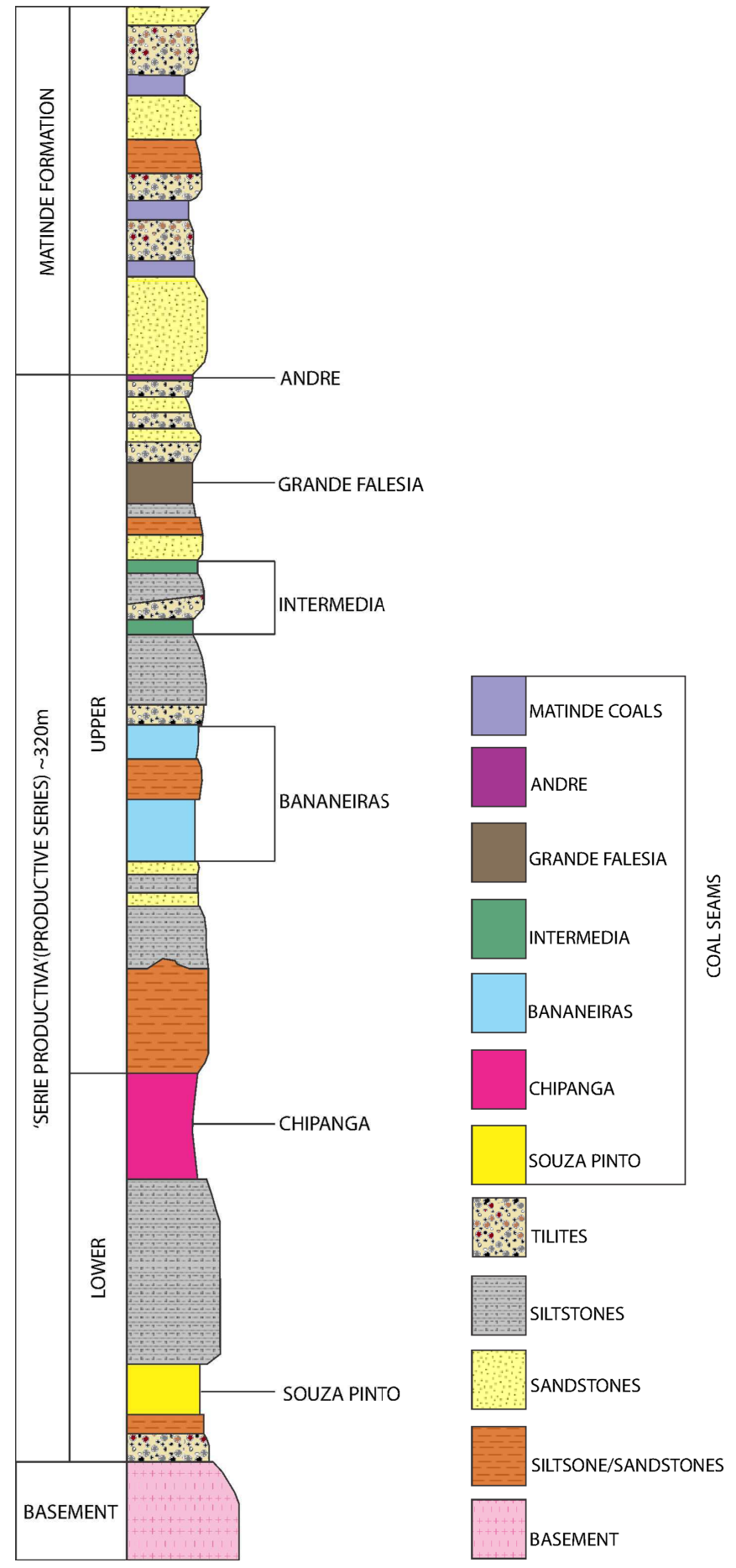

Figure 14: Stratigraphy of the Lower Karoo Supergroup in the Moatize coalfield. (From Swart et al., 2010).

Presently little mining is being undertaken; however Intra Energy's (http://www.intraenergycorp.com.au) $68 \mathrm{Mt}$ Malcoal Project in the northern basins commenced overburden removal late in 2013 and in 2014 had a production capacity of up to $8,000 \mathrm{tpm}$. The company plans to build a $130 \mathrm{MW}$ mine mouth power station on the project site.

\section{History}

The understanding of the Karoo sequence in Malawi is largely the result of work carried out by the Geological Survey since the 1950s (e.g. Thatcher (1974) and references therein).

\section{General Geology}

Two coalfields occur in the southern part of the country and 13 in the northern region. The best known deposits occur in the Ngana, Livingstonia, Lufira, Mwabvi, Lengwe, North Rukuru and Nthabile sub-basins. The southern basins are geologically linked to those of eastern Tete, whilst the northern basins are genetically linked to those in western Tanzania and northern Mozambique (the Metangula Coalfield) (Figure 15). The coal measures vary in thickness up to around $100 \mathrm{~m}$ in the north, and $600 \mathrm{~m}$ in the south of the country. The thin (generally less than $1 \mathrm{~m}$ ), multiple coal seams are generally hosted in mudstone beds. Sandstone-hosted coals are less common, but are notable in the south-western part of the Livingstonia Basin (Cooper and Habgood, 1959).

In the south, the Lower Zambezi Basin is bounded to the northeast by a major north-west trending fault, parallel to the regional structural grain of the underlying gneisses in the extreme north of the country (Bennett, 1989). The northern basins exhibit a regional dip to the east and are mostly half-grabens down faulted to the west along their eastern boundaries. These basins and their geology and coal qualities have been well documented by Bennett (1989) and the interested reader is referred to this publication, which is freely available on the internet.

The main basin in northern Malawi of importance in terms of its coal-bearing potential is the Livingstonia Basin, which represents the south-western extension of the Ruhuhu Basin in Tanzania, with which it shares many affinities (Figure 15).

\section{Coal Seams and Qualities}

Malawian coals are bituminous, with a high Ash (\%) content, high VM and low TS contents. The seams so far discovered are mostly less than one metre thick and display rapid vertical and lateral variations. Sandstone hosted related coals appear to be of better quality and more persistent than the coals associated with carbonaceous mudstones. Sandstone-hosted coals in the Livingstonia Basin have been worked on a small scale. At the Mchenga Mine a prominent seam of inter-banded dull and bright coal some 1.5-2.7 m thick occurs immediately beneath the $\mathrm{K} 3$ basal sandstone, which has been worked historically. The Kaziwiziwi 'main seam', which is also sandstonehosted, is $1.5-2.0 \mathrm{~m}$ thick, with the best coal occurring in the uppermost $0.75 \mathrm{~m}$. This seam has also been sporadically worked.

\section{Coal Resources}

Malawi has speculated coal resources of the order of $800 \mathrm{Mt}$ (BGS, 2009).

\section{Tanzania}

\section{Introduction}

Tanzania is currently also only a small scale producer and as the coalfields are remote from the industrial areas of the coast, and from most of the major mineral deposits, coal has not yet contributed significantly to the economy of the country. Currently Tanzania 
produces coal from two mines mainly for domestic use, such as power generation. Tancoal Energy, a joint venture between Australian-listed Intra Energy Corporation and the Tanzanian government, runs the Ngaka coal mine, while Tanzania's other mine at Kiwira is run by the state. According to the Intra Energy website, Ngaka was producing at 40,000 tpm in early 2015 . Production currently comes only from the Ruhuhu Basin (Figure 15) and Ilima Basin (Songwe-Kiwira Basins).

In the Ruhuhu Basin coal is currently being mined at the Tancoal mine, which is a joint venture between Australian junior Intra Energy (70\%) and the Tanzanian National Development Corp (30\%). In 2014 the State Mining Corporation (STAMICO), which has a 25 year license for the Songwe-Kiwira basins, released an expression of interest seeking a joint venture partner to fully finance and help operate a proposed coal and power project at Kiwira. Project goals included the: expansion of the existing underground mine from 150,000 tpa to 300,000 tpa; construction of a new opencast mine to produce $1.2 \mathrm{Mt}$ of coal annually; construction of a $200 \mathrm{MW}$ power plant (the Kiwira Mine-2 Power Station); and the construction of a $100 \mathrm{~km}$ power transmission line from the mine site to the town of Mbeya.

\section{History}

Coal occurrences in the Ruhuhu and Songwe-Kiwira basins were known as long ago as the end of the $19^{\text {th }}$ Century (Bornhardt, 1900), with Stockley (1932) originally describing the geology of the Ruhuhu Coalfield. From 1949-1957 extensive drilling programs in different Tanzanian coalfields were carried out by the Colonial Development Corporation in cooperation with the Geological Survey department of Tanganyika. Following on this work, a general account of the Karoo succession in Tanzania was provided by Quenell et al. (1956) and McKinlay (1965) summarised the geology and resources of the individual coalfields.

The coal potential of the Songwe-Kiwira basin was investigated by the coal investigation team of the People's Republic of China in 1968 and for many years the Ilima Mine in the Songwe-Kiwira basin was Tanzania's only operating coal mine. The Kiwira Coal Mine was developed in 1988 by STAMICO (with Chinese assistance), to replace the small privately owned Ilima Colliery.

In the early 1980s the Geological Survey of Tanzania made available all the previous reports and files connected to all coal

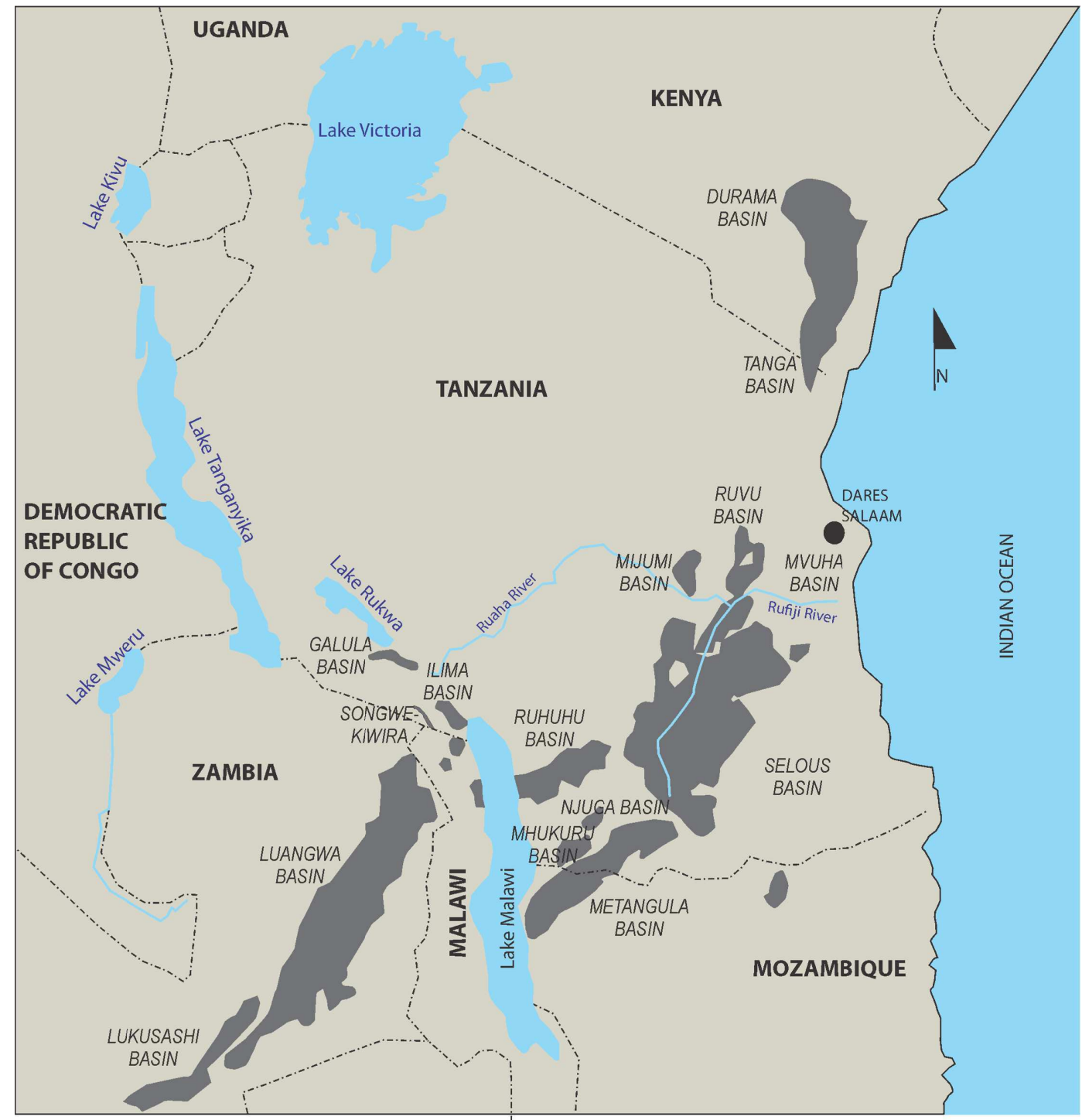

Figure 15: Karoo basins of East Africa including Tanzania, Northern Mozambique and Malawi. M= Mhukuru Basin; N = Njuga Basin (After Wopfner, 2002). 
exploration activities. A joint Tanzanian-German team worked on this data from 1984, leading to a number of excellent scientific publications concerning the coalfields (Casshyap et al., 1987; Kreuser and Semkiwa, 1987; Kreuser et al., 1990; Kreuser, 1991; Semkiwa et al., 1998; Semkiwa et al., 2003).

\section{General Geology}

The Karoo Supergroup equivalent deposits in Tanzania form a southwest trending strip or corridor, extending from the border with Kenya in the northeast to Lake Malawi in the southwest, from where they continue into Malawi (Figure 15). Coal seams are hosted in several separate, structurally controlled sub-basins, which strike northnortheast to northeast (Kreuser et al., 1990). The most important of these are the Ruhuhu and Songwe-Kiwira basins.

The Ruhuhu Basin is the only basin in Tanzania in which all of the lithostratigraphic units of the Karoo Supergroup are exposed, and it contains the best and most complete succession termed the Songea Group. This sequence is considered to be the type section of the Tanzanian and East African Karoo stratigraphy (Quennell et al., 1956; Wopfner, 2002) (Figure 2).

The Ruhuhu Basin contains several small coal basins (i.e. Mchuchuma, Ngaka North, Mbalawala, Lumecha), consisting of fault controlled half-grabens (Kreuser, 1991). Economic coal seams are hosted only in the Mchuchuma Formation. Descriptions of the Formation and its contained coals are given in Kreuser and Semkiwa (1987), Casshyap et al., (1987), Kreuser et al., (1990) and Kreuser (1991).

In the Ketewaka-Mchuchuma and Ngaka coalfields of the Ruhuhu Basin the Mchuchuma Formation has been sub-divided into two distinct facies (Semkiwa, 1992). The lower (or sandstonecoal facies) has thick coal seams with relatively low Ash (\%) and TS contents. It consists of a succession, up to $75 \mathrm{~m}$ in thickness, of coarse grained sandstones separated by coal seams. Up to six coal seams are recorded within the succession, two of which reach thicknesses exceeding $3.5 \mathrm{~m}$, with one attaining a maximum thickness of $7.5 \mathrm{~m}$ (Kreuser et al., 1990).

The upper facies consists of a succession of siltstone, coaly siltstone and mudstone bands separated by thin, impersistent coal seams, which are generally of poor quality. The succession is generally about $30-50$ m thick with about $10 \%$ composed of coal. The coal seams have relatively high Ash (\%) and TS contents compared to those in the lower sandstone-coal facies.

\section{Coal Seams and Qualities}

According to McKinlay (1965), the coal is a high to medium volatile bituminous coal. Kreuser et al. (1990) document coals with 9-28\% Ash and 20-30\% VM. Intra Energy (http://www.intra energycorp.com.au/) state that their resources exhibit high qualities with CVs of $25 \mathrm{MJ} / \mathrm{kg}$, Ash of $18 \%$, VM of $25 \%$ and TS of $0.5-$ $1.0 \%$.

\section{Coal Resources}

McKinlay (1965) considered that the Ruhuhu Basin held some $280 \mathrm{Mt}$ of coal, of which he believed some $124 \mathrm{Mt}$ were considered extractable. This number has subsequently grown and in 2013 the Tanzanian government listed coal resources of up to $5 \mathrm{Gt}$.

\section{Coal Deposits of the rest of Africa}

While space precludes as detailed an overview for the rest of Africa, a brief synthesis is included here for comparisons sake. The coal deposits in the rest of Africa range in age from the Carboniferous to the Miocene (Figure 1) and rank from anthracite to lignite. Of these, the economically most important are the Cretaceous bituminous and sub-bituminous coals, known from Algeria, Benin, Egypt, Libya, Mali, Mauritania, Niger, Nigeria, Senegal, and Sudan.

Of these countries Nigeria probably has the most potential, with coal resources believed to be in excess of 4 billion tonnes, including Africa's largest deposits of lignite (Ohimain, 2014). After wood, coal was in fact the first energy resource to be exploited in Nigeria, with the country having generated electricity from coal in the 1950s. Nigeria's coal industry however suffered a major blow in the late 1950s when oil was discovered. This had the combined effect of the two main consumers (the Nigerian Railway Corporation and Electricity Corporation of Nigeria) moving away from coal. Coupled to the effects of the Civil War, when many mines were abandoned, this effectively led to a decrease in coal production from a high of almost 1 Mt in 1959, to around 30,000 tpa in 2012.

Nigerian coal qualities (low sulphur and Ash\% content) however make the Nigeria coals ideal for coal-fired electric power plants. The current Government is therefore trying to revive the coal industry, by diversifying the electricity generation and by encouraging private sector participation. A figure of $30 \%$ electricity generation from coal is targeted for 2015 (Ohimain, 2014). Some of the Nigerian coals low thermoplastic properties mean they can also be used to produce formed-coke of metallurgical quality.

In neighbouring Niger these Cretaceous coals have not been exploited to any great extent, with coal production rather coming from Carboniferous strata in the Niger Basin, as well as Miocene brown coals and lignite, which are mined for thermal usage. Information as to production rates, type of coal mined, and the coal resources of Niger are however not freely available.

Carboniferous coals are also mined to a limited extent in Morocco. The coal deposits of Morocco occur in two distinct areas around Jerada and Ezzhiliga. According to the International Energy Statistics, the country has just less than $135 \mathrm{Mt}$ of recoverable coal, of which $90 \mathrm{Mt}$ is hard coal and $44 \mathrm{Mt}$ lignite.

Whilst developing a number of coal fired power stations, Egypt currently does not have any major coal production and limited coal resources, mainly in the Sinai Peninsula. Three main areas have been investigated, around Buda-Thora, Ayun-Musa and Maghara, with resources of up to $150 \mathrm{Mt}$ reported (Spalding, 1999). Up until 2009, when the mine was closed, the Maghara underground mine was reported to be producing around 360,000 tpa. Operations at this mine were approved to resume in 2014, with coal resources estimated at $21 \mathrm{Mt}$.

\section{Discussion and Conclusions}

From the above it is apparent that the coalfields of Africa (and SCA in particular) contain significant resources of both thermal and metallurgical coal. One should be mindful however of the fact that a significant portion of the stated resources are often grossly overestimated - and may not be supported by prospects for eventual economic extraction (a key component of a code compliant coal resource definition). It is however imperative to re-evaluate Africa's 
coal resource and reserve base to assist governments in formulating an efficient policy with regard to future coal energy supply.

All of Africa's coals are associated with non-marine to marginal marine terrestrial clastic sedimentary sequences, most commonly in SCA, mudstones and sandstones assigned to the Karoo Supergroup and its spatial and temporal equivalents. Whilst the coals in the rest of Africa span the Carboniferous to Miocene, most SCA coals formed during two periods of time, one in the Early Permian (ArtinskianKungurian) and the other in the Middle-Late Permian (UfimianKazanian). Early Permian SCA coals are most commonly lake shore margin or sandstone-hosted whereas Middle-Late Permian coals typically occur interbedded with mudstones. Unlike the Carboniferous coals from the northern hemisphere, SCA Permian coals generally have high Ash \% contents, and this is one of the key aspects that must be borne in mind when contemplating their exploitation.

Geologically, the pre-Karoo (basement) tectonic framework exerts an important control on the geometry and development of the SCA Karoo basins, as well as on the thickness of the sedimentary fill and coal seam characteristics. Two different (though related) tectonic regimes (compressional and extensional) existed during and after the formation of the SCA coal bearing basins, and this too played a major role in determining the style of coal deposit developed, as well as their present day structural complexity. Glacial preconditioning during the Late Palaeozoic Ice Age also played an important control, both on the generation of accommodation space, as well as on sediment supply during the early part of the coalfields histories. Changing floral communities and climatic overprint adds another layer of complexity.

Historically coal production in Africa has been the preserve of South Africa, which is by far the largest producer, utiliser and exporter of coal in the region. This has been augmented by far smaller scale production from Botswana, Zimbabwe, Zambia and Nigeria. More recently Mozambique has become a producer as well, surpassing Zimbabwe in 2012 to become the second-largest coal producer in Africa. Still, the combined production from the rest of the SCA and the North African countries reviewed, is less than $10 \%$ of South Africa's RoM output. It seems likely therefore that South Africa will continue as the dominant exporter of coal for the foreseeable future, with Mozambique eventually gaining an increased share.

Mozambique was supposed to be the game changer, but to date has been hamstrung by a lack of understanding of the coal qualities, infrastructural constraints and the cost of getting even coking coal to a port. Mozambique companies need to come up with answers as to what to do with the huge amount of thermal coal extracted, much of which is currently being disposed of.

This overview has shown that Botswana has huge coal resources (potentially the largest in the SCA region), however their potential cannot be unlocked at present due to infrastructural constraints, distance from a port, and due to the poor quality of the coals. Innovative solutions will have to be created and these will have to be based on a sound understanding of the coals chemical and physical properties.

In Zimbabwe, despite the huge potential that the coal resources offer, the country's coal mining industry remains subdued due to the lack of investment, poor infrastructure and poor transportation facilities. Furthermore Zimbabwe is under-utilising its coal (discarding as waste what could be a thermal product). Political will and innovative solutions will be required here as well to unlock value.

Zambia is a fairly junior player in the coal resource figures game, but at present is actively seeking to utilize the low grade (high Ash \%) coal for power generation at mine mouth via modern Circulating Fluidised Bed technology. Tanzania and Malawi have only recently developed fledgling coal industries, but both are looking inward, to their local markets and small to medium scale power generation.

Due to the poor qualities of the coal and the large transport distances, much of the SCA coal should be earmarked for domestic utilisation, and the innovative solutions alluded to above will have to take into account the rising opposition to coal usage, the depressed global coal markets and the energy challenge from gas.

\section{Acknowledgements}

Thanks are extended to Professor Bruce Cairncross and Mr Coenie van Niekerk who critically reviewed this manuscript.

\section{References}

Anhaeusser, C.R. and Maske, S., 1986. Mineral Deposits of Southern Africa, vol. II. The Geological Society of South Africa, 10212335.

Barber, B., 1988. An assessment of the coal resources in northern Zimbabwe. In: Records of Zimbabwe Coalfields, volume XVII. Zimbabwe Geological Survey, Harare, 15pp.

Bennett, J.D., 1989. Review of Lower Karoo coal basins and coal resource development in parts of central and southern Africa with particular reference to northern Malawi. British Geological Survey Technical Report WC/89/21, 1-73.

Beukes, N.J., Siepker, E.H. and Naudé, F., 1991. Genetic stratigraphy of the Waterberg Coalfield. Unpaginated Abstract, Conference on South Africa's Coal Resources, Witbank November 1991. Geological Society of South Africa, 8pp. Downloadable at: http:/ $/ w w w . b g s . a c . u k /$ research/international/malawi/mineral_ potential_of_malawi_3.pdf.

Bornhardt, W., 1900. Zur Oberfl•achengestaltung und Geologie Deutsch-Ostafrikas. Dietrich Reimer Verlag, Berlin, 595pp.

Bredell, J.H.,1987. South African coal reserves, explained and analysed. Internal Report No. 1987-0154. Geological Survey of South Africa.

British Geological Survey., 2009. Mineral Potential of Malawi 3. Mineral deposits associated with sedimentary and volcanic cover rocks: Karoo and post-Karoo (coal, uranium, industrial minerals and gemstones).

Cadle, A.B., Cairncross, B., Christie, A.D.M. and Roberts, D.L., 1993. The Karoo Basin of South Africa: type basin for coal-bearing deposits of southern Africa. International Journal of Coal Geology, 23, 117-157.

Cairncross, B., 1980. Anastomosing river deposits: palaeoenvironmental control on coal quality and distribution, northern Karoo Basin. Transactions of the Geological Society of South Africa, 83, 327-332.

Cairncross, B., 1986. Depositional Environments of the Permian Vryheid Formation in the East Witbank Coalfield, South Africa: A Framework for Coal Seam Stratigraphy, Occurrence and Distribution. Unpublished PhD Thesis, University of the Witwatersrand, Johannesburg, $232 \mathrm{pp}$.

Cairncross, B., 2001. An overview of the Permian (Karoo) coal deposits of southern Africa. Journal of African Earth Sciences, 33, 529-562.

Cairncross, B. and Cadle, A.B., 1988. Palaeoenvironmental control on coal formation, distribution and quality in the Permian Vryheid Formation, East Witbank Coalfield, South Africa. International 
Journal of Coal Geology, 9, 343-370.

Casshyap, S.M., Kreuser, T and Wopfner, H., 1987. Analysis of cyclical sedimentation in the lower Permian Mchuchuma coalfield (South-West-Tanzania). Geologische Rundschau, 76 (3), 869-883.

Catuneanu, O., Hancox, P.J. and Rubidge, B.S., 1998. Reciprocal flexural behaviour and contrasting stratigraphies: a new basin development model for the Karoo retroarc foreland system, South Africa. Basin Research 10, 417-439.

Catuneanu, O., Hancox, P.J., Cairncross, B. and Rubidge, B.S., 2002. Foredeep submarine fans and forebulge deltas: orogenic offloading in the underfilled Karoo Basin. Journal of African Earth Sciences 35, 489-502.

Catuneanu, O., Wopfner, H., Eriksson, P.G., Cairncross, B., Rubidge, B.S., Smith, R.M.H. and Hancox, P.J. (2005). The Karoo basins of south-central Africa. Journal of African Earth Sciences, 43, 211-253.

Chatupa, J.C., 1991. Notes accompanying the revised inventory of the coal resources of Botswana. Geological Survey of Botswana, Unpublished report.

Clark, G. C., Lock, N. P. and Smith, R. A., 1986. Coal resources of Botswana. In: Anhaeusser, C. R. and Maske, S. (eds.). Mineral Deposits of Southern Africa. Geological Society of South Africa, Johannesburg, 2071-2085.

Cole, D.I., 1992. Evolution and development of the Karoo Basin. In: DeWit, M.J., Ransome, I.G.D. (Eds.), Inversion Tectonics of the Cape Fold Belt. Karoo and Cretaceous Basins of Southern Africa. A.A. Balkema, Rotterdam, pp. 87-99.

Cooper, W.G.G. and Habgood, F., 1959. The geology of the Livingstonia coalfields. Bulletin Geological Survey Nyasaland, 11, 51pp.

Denman, P.D. and Money, N.J., 1968. The coal resources of the Zambezi Valley. V. Siankondobo - the north-eastern area. Preliminary report. Economic Report Geological Survey Zambia, 23. $14 \mathrm{pp}$

De Jager, F.S.J., 1983. Coal reserves of the Republic of South Africa - An evaluation at the end of 1982. Bulletin 74. Department of Mineral and Energy Affairs-Geological Survey, Pretoria.

Dreyer, C., 2011. An overview of the geology of the Waterberg Coalfield: implications for future exploitation. Unpublished Conference Abstract, FFF Waterberg Coal Conference.

Drysdall, A.R., Denman, P.D., Money, N.J., Pagella, J.F. and Premoli, C., 1967. The coal resources of the Zambezi Valley. III. Siankondobo - the northern part of the Kazinze Basin. Economic Report, Geological Survey Zambia 15, 70pp.

Duguid, K.B., 1986. The Coalfields of Zimbabwe. In: Anhaeusser, C.R. and Maske, S., (Eds). Mineral Deposits of Southern Africa, vol. II. The Geological Society of South Africa, 20872089.

Faure, K., Willis, J.P. and Dreyer, J.C., 1996. The Grootegeluk Formation in the Waterberg Coalfield, South Africa: facies, palaeoenvironment and thermal history - evidence from organic and clastic matter. International Journal of Coal Geology, 29, 147186.

Fourie, C.J.S., Henry, G. and Marè, L.P., 2009. The structure of the Karoo-age Ellisras Basin in Limpopo Province, South Africa in the light of new airborne geophysical data: a preliminary report. 11th SAGA Biennial Technical Meeting and Exhibition, Swaziland, 27-32.

Gair, H.S., 1959. The Karroo System and coal resources of the Gwembe District, north-east section. Bulletin Geological Survey Northern Rhodesia 1, 88pp.

Golding, A., 2015. Botswana Coal - Quo Vadis II. Presentation at the FFF Solid Fossil Fuels in southern Africa and Madagascar conference, March 2015.
Green, D., 1957. Coal exploration: records of boreholes. Volume 1. Geological Survey, Botswana, 260pp.

Green, D., Crockett, R.N. and Jones, M.T., 1980. Tectonic Control of Karoo Sedimentation in mid-eastern Botswana. Transactions of the Geological Society of South Africa, 83, 215-219.

Grodner, M.W., 2002. A Regional, 3-D Computer-based Sedimentological Model of the Permian Witbank Coalfield, South Africa. Unpublished MSc Thesis, Rand Afrikaans University, South Africa, $82 \mathrm{pp}$.

Grodner, M.W. and Cairncross, B., 2003. A regional scale 3-D model of the Witbank Coalfield, Northern Karoo Basin, South Africa. South African Journal of Geology, 106, 249-264.

GTK Consortium Geological Surveys in Mozambique 2002-2007, 2008. In: Yrjö, Pekkala, Tapio, Lehto, Hannu, Mäkitie (Eds.). Geological Survey of Finland, Special Paper, 48, 7-22.

Hancox, P.J. and Götz, A.E., 2014. South Africa's coalfields - A 2014 perspective. International Journal of Coal Geology, 132, $170-254$

Hartzer, F.J. 2008. 1:100 000 Scale Geological Map of Mozambique. Council for Geoscience, South Africa; Direcçäo Nacional de Geologica, Mozambique and Gondwana Empreendimento e Consultorias, Limitada, Mozambique.

Hatton, W. and Fardell, A., 2012. New discoveries of coal in Mozambique - Development of the coal resource estimation methodology for International Resource Reporting Standards. International Journal of Coal Geology, 89, 2-12.

Hlatywayo, D.J., 1995. Fault-plane solutions of the Deka Fault zone and mid-Zambezi Valley. Geophysical Journal International, 120, 567-576.

Holland, M.J., Cadle, A.B., Pinheiro, R. and Falcon, R.M.S., 1989. Depositional environments and coal petrography of the Permian Karoo Sequence: Witbank Coalfield, South Africa. International Journal of Coal Geology, 11 (2), 143-169.

Johnson, M.R., Van Vuuren, C.J., Hegenberger, W.F., Key, R. and Shoko, U., 1996. Stratigraphy of the Karoo Supergroup in southern Africa: an overview. Journal of African Earth Sciences, 23 (1), 3-15.

Kreuser, T., 1991. Facies evolution and cyclicity of alluvial coal deposits in the Lower Permian of East Africa (Tanzania). Geologische Rundschau, 80 (1), 19-48.

Kreuser, T. and Semkiwa, P.M., 1987. Geometry and depositional history of a Karoo (Permian) coal basin (Mchuchuma-Ketewaka) in SW Tanzania. Neues Jahrbuch für Geologie und Paläontologie, 2, 69-98.

Kreuser, T., Wopfner, H., Markwort, S., Kaaya, C.Z., Semkiwa, P.M. and Aslanindis, P., 1990. Depositional evolution of a PermoTriassic basin in Tanzania with reference to the economic potential. Journal of African Earth Sciences, 10, 151-167.

Lächelt, S., 2004. The Geology and Mineral Resources of Mozambique. National Directorate of Geology, Chapter 7, 223231.

Le Blanc Smith, G., 1980a. Genetic stratigraphy of the Witbank Coalfield. Trans. Geol. Soc. S. Afr. 83 (3), 313-326.

Le Blanc Smith, G., 1980b. Genetic Stratigraphy and Palaeoenvironmental Controls on Coal Distribution in the Witbank Basin Coalfield. Unpublished PhD thesis, University of the Witwatersrand, $242 \mathrm{pp}$.

Le Blanc Smith, G. and Eriksson, K.A., 1979. A fluvioglacial and glaciolacustrine deltaic depositional model for PermoCarboniferous coals of the northeastern Karoo Basin, South Africa. Palaeogeography Palaeoclimatolology Palaeoecology, 27, 67-84.

Lightfoot, B., 1914. The Geology of the Northwestern Part of the Wankie Coal Field. Geological Survey of Southern Rhodesia, 
Bulletin No. 4, 3-49.

Lloyd, A., 2015. Tete Coal Basin - What do we know? What do we still have to learn? Presentation delivered at the Fossil Fuel Foundation Solid fossil fuels in southern Africa and Madagascar, March 2015.

Maponga, O., 2015. The Hwange Coalfield Zimbabwe. Presentation at the FFF Solid Fossil Fuels in southern Africa and Madagascar conference, March 2015.

Mathisen, M.B. and Roscoe, W.E., 2012. The Dibwe East Project, Southern Province, Republic of Zambia. Technical Report prepared for Denison Mines Zambia Limited, 122pp. Available on $\underline{\mathrm{h} t t p}: / / w w w$. sedar.com.

Matyanga, D.D., 2012. Coal Production in Zimbabwe past and present and its significance to the economy. Presentation at the FFF and IEA Zimbabwe Indaba, March 2012.

Maufe, H.B., 1914. The Coal Resources of Rhodesia. Geological Survey of Southern Rhodesia, Bulletin No. 4, 56-61.

McKinlay, A.C.M., 1965. The coalfields and the coal resources of Tanzania. Geological Survey of Tanzania, Bulletin 38, 82pp.

Merrill, M.D. and Tewalt, S.J. 2008. GIS Representation of CoalBearing Areas in Africa. U.S. Geological Survey Open-File Report 2008-1258, available online at http://pubs.usgs.gov/of/ 2008/1258/.

Meyer, P., 2015. Mozambique and Botswana Coal Fields: developments in the past 5 years, or not. Presentation at the FFF Solid Fossil Fuels in southern Africa and Madagascar conference, March 2015.

Modie, B.N., 2007. The Palaeozoic Palynostratigraphy of the Karoo Supergroup and palynofacies insight into palaeoenvironmental interpretations, Kalahari Karoo Basin, Botswana. Unpublished $\mathrm{PhD}$ thesis, Universite de Bretagne Occidentale, France, 300pp.

Mutsinya, P., 2012. The Lubimbi Coalfield. Presentation delivered at the Fossil Fuel Foundation Zimbabwe Coal Indaba, March 2012.

Nyambe, I.A., 1999. Sedimentology of the Gwembe Coal Formation (Permian), Lower Karoo Group, mid-Zambezi Valley, southern Zambia. In: Smith, N.D. and Rogers, J. (Eds). Fluvial Sedimentology VI: International Association of Sedimentologists Special Publication 28, 409-434.

Nyambe, I.A. and Utting, J., 1997. Stratigraphy and palynostratigraphy, Karoo Supergroup (Permian and Triassic), midZambezi Valley, southern Zambia. Journal of African Earth Sciences, 24 (4), 563-583.

Ohimain, E.I., 2014. Can Nigeria Generate 30\% of her Electricity from Coal by 2015? International Journal of Energy and Power Engineering, 3 (1), 28-37.

Pagella, J.F. and Drysdall, A.R., 1966. The coal resources of the Zambezi Valley. I. Siankondobo - the Kazinze Basin. Preliminary report. Economic Report Geological Survey Zambia 13, 89pp.

Palloks, H.H., 1984. An assessment of some of the coal deposits in north-west Zimbabwe. Mineral Resources Series Geological Survey Zimbabwe, 19.

Prevost, X., 2015. The Changing South African Coal Mining Industry. Presentation at the HIS Energy South African Coal Exports Conference 2015, Cape Town.

Pysklywec, R.N. and Mitrovica, J.X., 1999. The role of subduction induced subsidence in the evolution of the Karoo Basin. Journal of Geology, 107, 155-164.

Quennell, A.M., McKinlay, A.C.M. and Aitken, W.G. 1956. Summary of the geology of Tanganyika. Part I: Introduction and stratigraphy. Memoir Geological Survey Tanganyika, 1. 265pp.

Ryan, B., 2014. Coal reserves study gives lie to Eskom supply scare. BusinessDay Live. http://www.bdlive.co.za/business/mining/ 2014/04/17/coal-reserves-study-gives-lie-to-eskom-supply-scare
SAMREC, 2007. The South African Code for the Reporting of Exploration Results, Mineral resources and Mineral Reserves (The SAMREC Code). South African Mineral Resource Committee, $1-22$.

SANS 10320: 2004. South African National Standard: South African Guide to systematic evaluation of coal resources and coal reserves. Standards South Africa, 140pp.

Semkiwa, P.Z., 1992. Depositional environment and coal petrography of Permian coal deposits in Karoo Basins of SW Tanzania. Geologisches Institut, Universität Köln, Sonderveröffentlichungen 84, 184pp.

Semkiwa, P.Z, Kalkreuth, W., Utting, J., Mayagilo, F., Mpanju, F. and Hagemann, H., 1998. The geology, petrology, palynology and geochemistry of Permian coal basins in Tanzania: 1. NamweleMkomolo, Muze and Galula coalfields. International Journal of Coal Geology, 36, 63-110.

Semkiwa, P.Z., Kalkreuth, W., Utting, J., Mpanju, F. and Hagemann, H., 2003. The geology, petrology, palynology and geochemistry of Permian coal basins in Tanzania: 2. Songwe-Kiwira Coalfield. International Journal of Coal Geology, 55, 157-186.

Segwabe, T., 2008. The Geological Framework and Depositional Environments of the Coal-Bearing Karoo Strata in the Central Kalahari Karoo Basin, Botswana. Unpublished MSc thesis, Rhodes University, 113 pp.

Smith, R.A., 1984. The Lithostratigraphy of the Karoo Supergroup in Botswana. Geological Survey of Botswana, Bulletin, 26, 239pp.

Snyman, C.P., 1998. Coal. In: Wilson, M.G.C. and Anhaeuesser C.R. (editors), The Mineral resources of South Africa, Hand Book 16. Council for Geoscience publication, 16, 136-205.

South African Committee for Stratigraphy (SACS), 1980. Stratigraphy of South Africa. Part 1 (Comp. L.E. Kent). Lithostratigraphy of the Republic of South Africa, South West Africa/Namibia and the Republics of Bophuthatswana, Transkei and Venda. Handbook Geological Survey South Africa, 8, 690pp.

Spalding, B.R., 1999. An assessment of reserves, production and export possibilities of coal in African countries. Unpublished MSc thesis, Rand Afrikaans University, 163 pp.

Stockley, G. M., 1932. The geology of the Ruhuhu Coalfields, Tanganyika Territory. Quarterly Journal of the Geological Society, London, 88, 610-622.

Sullivan, J.H., Camisani-Calzolari, F.A. and Eriksson, P.G., 2013. The practical application of vector processed densities in proving the lateral continuity of coal zones and samples in the Ellisras Basin, South Africa. South African Journal of Geology, 116 (2), 323-345.

Swart, J., Bertinshaw, R., Bonham-Carter, S. and Tattersall, A., 2010. External Audit of Coal reserves for Moatize Coal Project. Internal report for Vale South Africa (Pty) Limited by Golder Associates.

Tavener-Smith, R., 1960. The Karroo System and coal resources of the Gwembe District, south-west section. Bulletin Geological Survey Northern Rhodesia 4, pp. 84.

Tavener-Smith, R., 1962. Karroo sedimentation in a part of the midZambezi Valley. Transactions of the Geological Society of South Africa 65, 43-74.

Thatcher, E.C., 1974. The geology of the Nyika area. Bulletin Geological Survey Malawi, 40, 90pp.

Thompson, A.R., 1914. The Wankie Colliery and Method of Working the Coal. Geological Survey of Southern Rhodesia, Bulletin No. $4,50-55$.

Thompson, A.O., 1981. The geology of the Lubimbi, Dahlia and Hankano coalfields, Wankie and Lupane districts. Bulletin Geological Survey Zimbabwe, 88. 88pp.

Thornton, R., 1859. On the coal found by Dr. Livingstone at Tete, on the Zambesi, South Africa. Quarterly Journal of the Geological 
Society, 15 (1-2), 556.

Uys, J., 2007. Lithostratigraphy, Depositional Environments and Sedimentology of the Permian Vryheid Formation (Karoo Supergroup), Arnot North, Witbank Coalfield, South Africa. Unpublished MSc Thesis, University of Johannesburg, 112pp.

Vasconcelos, L.S., 2000. Overview of the Moatize Coal Basin geology,

Tete province, Republique of Mozambique. Chronicles of Mineral Research and Exploration 538, 25-36.

Vasconcelos, L.S., 2013. Coal Deposits in Mozambique - An Overview. Presentation at the FFF Mozambique Coal Conference, October 2013, Johannesburg, South Africa.

Veevers, J.J., Cole, D.I. and Cowan, E.J., 1994. Southern Africa: Karoo Basin and Cape Fold Belt. In: Veevers, J.J., Powell, J.J.,
McA, C. (Eds.), Permian Triassic Pangean Basins and Foldbelts along the Panthalassan Margin of Gondwanaland. Geological Society of America Memoir, 184, 223-279.

Vergeer, J.C., 2010. Morupule Colliery - "Current \& Future Prospects". Presentation delivered at the Botswana Coal and Energy Conference, September 2010.

Winter, M.F., 1985. Lower Permian Paleoenvironments of the Northern Highveld Coalfield and Their Relationship to the Character of the Coal Seams. Unpublished PhD Thesis, University of the Witwatersrand, Johannesburg, 254pp.

Wopfner, H., 2002. Tectonic and climatic events controlling deposition in Tanzanian Karoo basins. Journal of African Earth Sciences 34, 167-177.

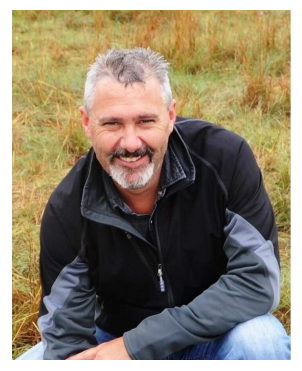

John Hancox is a graduate of the University of the Witwatersrand with a B.SC. (Hons.) Geology/Palaeontology and a Ph.D. focussed on the formation and fill of the main Karoo Basin of South Africa. Whilst in academia he was involved in research in the fields of Sedimentology, Palaeontology, Basin Analysis and Economic Geology, and has over seventy publications in recognized peer reviewed journals. This work set up a lifetime love of the rocks of the Karoo Supergroup and a career in the coalfields of South-Central Africa, with aspects covered ranging from grass roots exploration to core logging and sampling, database management, stratigraphic sequence determination and modelling. 